\title{
PLANETARY PERMO-CARBONIFEROUS ICE AGE - BANK OF PALEONTOLOGICAL AND GEOLOGICAL FACTS FOR DISPROVING THE GLACIAL THEORY
}

\author{
V. G. Chuvardinsky \\ Central Kola Geological Expedition \\ 23A Komsomolskya street, Monchegorsk, Murmansk region, 184511, Russia \\ E-mail: Lavrentieva@arcticsu.ru
}

\section{ПЛАНЕТАРНЫЙ ПЕРМСКО-КАМЕННОУГОЛЬНЫЙ ЛЕДНИКОВЫЙ ПЕРИОА - КЛАДЕЗЬ ПАЛЕОНТОЛОГИЧЕСКИХ И ГЕОЛОГИЧЕСКИХ ААННЫХ АЛЯ УПРАЗДНЕНИЯ ЛЕАНИКОВОЙ ТЕОРИИ}

\author{
В. Г. Чувардинский \\ Центрально-Кольская геологическая экспедиция, \\ Россия, 184511, Мурманская область, г. Мончегорск, ул. Комсомольская, 23 А \\ E-mail: Lavrentieva@arcticsu.ru
}

\begin{abstract}
The hypothesis of Permo-Carboniferous glaciation appeared for the first time in the middle of XIX century based on findings of tillite outcrop and striated boulder in India and Australia. After that such boulder deposits were found in South and Equatorial Africa, Europe, Kazakhstan, South and North America, on the Arabian Peninsula. The latest place where tillites were found is Antarctica. Over 150-200 years the hypothesis turned into an unshakeable theory and, together with the theory of powerful Quaternary glaciation, was wildly introduced into Earth science (geoscience), it was definitely considered as a fundamental and epoch-making scientific achievement. During this period the scientific groups from different countries - botanists, zoologists, paleogeographers, climatologists and geologists collected rich, sometimes unique, factual material concerning plant and animal life of the late Paleozoic and wide formations of coal deposits. The paleogeography reconstructions of almost global glaciation with ice thickness of $6 \mathrm{~km}(!)$ were also informative; this glaciation was called "The Great PermoCarboniferous ice age". It was impossible to think about debunking this theory. Therefore, it is worth mentioning that many scientists, both foreign and Russian ones, can be regarded as our extramural co-authors. The fact that we, unlike them, try to disprove the glacial theory, does not change the matter - it was impossible to prove the absence of this glaciation without the powerful glacial doctrine created by the scientific community and without huge factual material collected by them. The geological features of the Permo-Carboniferous glaciation are based on the same criteria as for the Quaternary glaciation. First of all, this is "an ice exaltation relief" - they are roche moutonnée (sheepbacks), polished rocks, striation, furrows on bedrock and boulders, tillites. It allows using the well-known principle of actuality. The author's multi-year research has proved that "exaration" types of relief of the Quaternary time (fjords, skerries, lake basins in bedrock, drumlins) were formed due to the disjunctive dislocations of different rank and sequence. They occupy their normal place in the ensemble of paragenetic structures that accompany faulting. A detailed study of fault systems, especially shifts and zones of their dynamic influence, showed a paragenetic connection of the most striking "exaration" types of relief (roche moutonnée (sheepbacks), fleecy rock, rocks polishing, striations and furrows) with structures such as near-surface thrusts, upcast faults, downcast faults and shifts. Mass development of the above-mentioned relief forms is observed at the ends of the large shifts and they are made of fault planes and slickensides of the listed near-surface disjunctive structures upthrow sides of which are mostly destroyed into a blocky-boulder component. There is rich paleontological material concerning the period of vast Permo-Carboniferous glaciation that covered virtually the entire globe, this material allows reconstructing actual landscapes and climates of that epoch. Extremely favorable conditions for the development of terrestrial vegetation were created in the Carboniferous period. Warm, humid climate dominated in vast territories of the globe. A sultry, heavy atmosphere reigned in the Carboniferous forests. The deposits of coal amounting to nearly $30 \%$ of the world's reserves of this fuel were formed. And climate of the Permian period was generally the warmest of the formerly dominated Paleozoic. Tillites. Considering that the remnants of the Paleozoic vegetation are often found in the cut layers of the tillites, and the tillites are interbedded with the lenses and layers of coal, it is high time to recall that the tillites are a tectonic breccia, tectonic melange, and boulders with scars and striations are the most reliable indicator of their tectono-dynamic processing. As for the polished and grooved "glacial bed" of the bedrock, as well as roche moutonnée (sheepbacks) and fleecy rocks that are associ-
\end{abstract}


ated with the tillites, this is just a clear illustration of tectonic subsurface shear displacements of fault and thrust types. This allows closing the topic about the grand Permo-Carboniferous glaciation. Glaciology. But there is additional material in support of these conclusions - they relate to the glacial theory in the whole. By now, due to the work of glaciologists, geologists, and geophysicists, the dynamics and tendency of glacial drifts, throughout its mass, have been studied. The results of ice through drilling (to the bedrock) in Antarctica and Greenland, obtained within the framework of the International Projects, are of great importance. A thorough study of many kilometers of ice columns, as well as the study of vertical ice breaks and the study of ice in tunnels broken through the base of glaciers, produced unexpected results. It turned out that instead of moraine-containing ice mass, entirely filled with huge blocks and boulders (as is customary depicted in diagrams and drawings in the textbooks on general and quaternary geology and geomorphology), only inclusions of sandy-loamy and fine-earth substance are traced in continental ice. Even in the bottom of the glaciers - where it is customary to place a wide basal moraine filled with huge blocks and iron-like boulders, only small lenses and clots of loamy and sandy-loamy substance, and rarely sand grains are fixed. These mineral inclusions are contained in hundredths of a percent and are mainly represented by volcanic ash, microcosmic particles, aeolian dust of distant deserts, rare inclusions of fine-earth terrigenous material, as well as spores and pollen. There's no need to mention tillites with huge boulders! All that is left for the proponents of the glacial doctrine, who depict decimetric dust-like moraines without boulders. An important function of glaciers is to conserve the subglacial geological-topographic surface.

Key words: Permo-Carboniferous ice age, tillite, ice exaltation relief, erratiecs, coal formations, plate-tectonics, calamiteles, filices, cordaites.

For citation: Chuvardinsky V.G. Planetary permian-carboniferous ice age is a bank|fund of paleontological and geological facts for the abolition of glacial theory. Russian Journal of Ecosystem Ecology. 2017;2(3). Available from: https://doi.org/10.21685/2500-0578-2017-3-1

Аннотация. Гипотеза о пермско-каменноугольном оледенении впервые возникла в середине XIX в. на основе находок в Индии и Австралии обнажений тиллитов и штрихованных валунов. Затем подобные валунные отложения были найдены в Южной и Экваториальной Африке, в Европе, Казахстане, Южной и Северной Америке, на Аравийском полуострове. Позже всего тиллиты были обнаружены в Антарктиде. За полтора-два века гипотеза превратилась в незыблемую теорию, и вместе с теорией мощного четвертичного оледенения широко внедрилась в науки о Земле, стала безоговорочно считаться фундаментальным, эпохальным научным достижением. Научные коллективы разных стран - ботаники, зоологи, палеогеографы, климатологи и геологи за этот период собрали богатейший, подчас уникальный фактический материал по растительному и животному миру позднего палеозоя, по формированию мощных залежей каменного угля. Поучительны и палеогеографические реконструкции чуть ли не глобального оледенения с толщиной льда 6 км(!), получившего титульное название «Великий пермско-каменноугольный ледниковый период». Страшно было и подумать о его развенчании. Поэтому нелишне информировать, что многих ученых, как западных, так и российских, можно считать моими заочными соавторами. Тот факт, что я, в отличие от них, пытаюсь упразднить ледниковую теорию, не меняет дела - без созданной научным сообществом могущественной ледниковой доктрины, без огромного фактического материала, собранного ими, невозможно было доказать отсутствие этого оледенения. В основу геологических признаков пермско-каменноугольного оледенения положены те же критерии, что и для четвертичного оледенения. Прежде всего это «ледниково-экзарационный» рельеф - бараньи лбы, полированные скалы, штрихи, борозды на коренных породах и валунах, тиллиты. Это позволяет применять уже давно известный, проверенный принцип актуализма. Многолетние исследования автора доказали, что «экзарационные» типы рельефа четвертичного времени (фьорды, шхеры, озерные котловины в коренных породах, друмлины) своим формированием обязаны разрывным дислокациям разного ранга и порядка. Они занимают свое место в ансамбле парагенетических структур, которые сопровождают разломообразование. Детальное изучение систем разломов, особенно сдвигов и зон их динамического влияния, показало парагенетическую связь наиболее ярких «экзарационных» типов рельефа (бараньих лбов, курчавых скал, полировки пород, систем штрихов и борозд) с такими структурами, как приповерхностные надвиги, взбросы, сбросы и сдвиги. Массовое развитие перечисленных форм рельефа наблюдается на окончаниях крупных сдвигов; они представляют собой сместители и зеркала скольжения перечисленных приповерхностных разрывных структур, висячие крылья которых большей частью разрушены на глыбово-валунную составляющую. Для периода грандиозного, «охватившего практически весь Земной шар» пермскокарбонового оледенения имеется богатый палеонтологический материал, позволяющий реконструировать фактические ландшафты и климаты той эпохи. В каменноугольном периоде создались чрезвычайно благоприятные условия для развития наземной растительности. Теплый, влажный климат господствовал на значительных пространствах земного шара. Душная, тяжелая атмосфера царила в каменноугольных лесах. Формировались залежи каменных углей, составляющих почти 30 \% мировых запасов этого топлива. А климат пермского периода был вообще самым теплым из ранее господствовавших в палеозое.

Ключевые слова: пермско-каменноугольный ледниковый период, тиллиты, ледниково-экзарационный рельеф, эрратические валуны, угленосные формации, тектоника плит, хвощи, папоротники, кордаиты. 


\section{Introduction}

Global transformations of our planet surface, with different degrees of reliability, can be traced from the Archaean to the Cenozoic era. During these 3,5-4 billion years of the Earth existence, it is customary to distinguish special glacial periods on its surface, including "total glacial periods", when the planet was completely covered by ice mass.

Relying on numerous literary sources of foreign scientists, N. M. Chumakov, a well-known Soviet scientist, a proponent of the large Precambrian and Phanerozoic glaciations, suggests the scheme of global glacier system in his book "Glaciations of the Earth. History, stratigraphic significance and role in the geosphere" (2015) [1]. He identifies 5 glacial eras (glaciera) from the late Archaean to the Quaternary time. Each glaciera consists of three or six glacial periods, one of which in its turn includes a number of glacial and interglacial epochs. Due to such system, the number of glaciations becomes simply arbitrary, convenient for any glacial school, foreign or national (Fig. 1).

Different scientific schools determine from 1 glaciation (mono-glacialists) to 4-6 glaciations (poly-glacialists) even for the Quaternary period, which lasts about 1 million years, and some scientists identify up to 17-22 glaciations in that period. They could be named "super-glacialists". Another remarkable thing in current situation is as follows: the representatives of any scientific glacial school receive funding from the Russian Foundation for Basic Research for their articles and even for abstracts and it seems that as the number of glaciations increases, so will the amount of money the glacialists get.

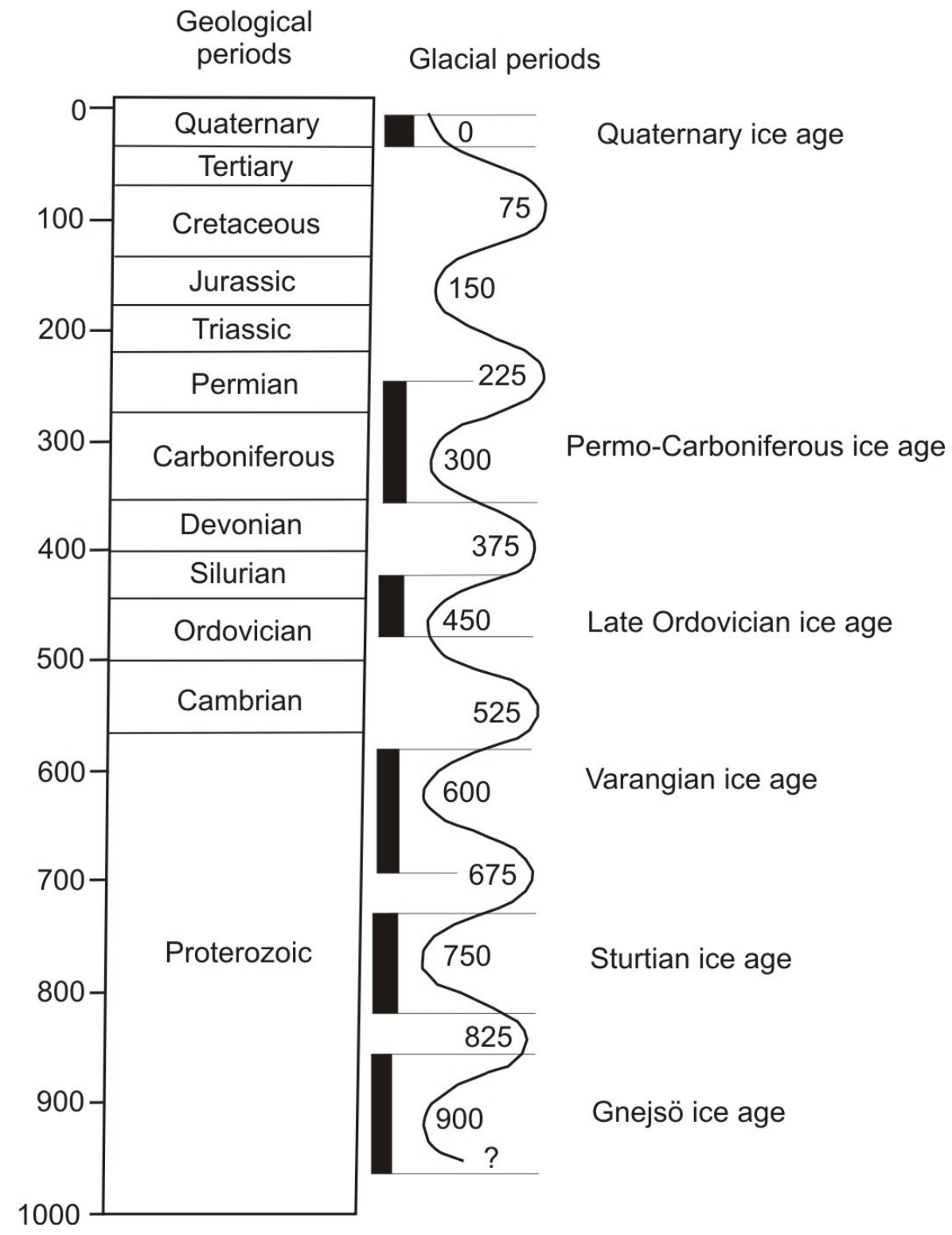

Fig. 1. Global glacial cycles (black lines) in Earth history (figures are geological and glacial periods in million years). By B. John, E. Derbisher, G. Young, R. Fairbridge, J. Andrews [2] 
As for the Permo-Carboniferous ice age, the most prominent foreign scientists specify that this glaciation lasts 100 million years - in the interval between 340-240 million years ago. And its unusually cold impact continued for millions of years. Scientists do not explain when and how the huge deposits of coal were formed in the course of this glacial period.

\section{Aspects of quaternary geology, geomorphology and glaciology in the context of issues posed by the glacial theory}

These aspects and issues were previously considered by the author in few monographs $[3-5,7$, 10-12, 23-28]. Having analyzed these woks, Russian scientists P. K. Skufyin, Yu. N. Golubchikov, S. P. Evdokimov and A. A. Predovsky prepared a digest review "Chuvardinsky's Antiglacial (generalized geological) conception" and it was published in the "Russian Journal of Ecosystem Ecology"， № 4, 2016 (http://creativecommons.org/ licenses/by/4.0/). They fully supported the new antiglacial (generally geological) conception proposed by Vasily Chuvardinsky with respect to the Quaternary period. The strong support of wellknown geologists and geographers - the authors of the above mentioned digest review contributed to the writing of this manuscript on disproving "Great Permian-Carboniferous glaciation". Chuvardinsky's images and illustrations have been earlier published in his books; they were also used in the article by P. K. Skufyin, etc. in "Russian Journal of Ecosystem Ecology".

\section{Origin of "ice exaration" types of relief}

It is generally considered that the most important and graphic signs of past glaciations are "ice exaration" types of relief: fjords, skerries, lake kettles, sheepbacks, curly rocks, polished crystal rocks and rock furrows/striae.

These formations are a "stronghold" of the glacial theory; they provide basis for the ideas of huge glaciations, covering plains of the northern hemisphere - with ice cover thickness amounts to 3,5$4,5 \mathrm{~km}$.

Due to the long-term studies conducted on the Baltic shield, an area with classical and diverse types of ice exaration relief, V. G. Chuvardinsky managed to conclude that this relief had a fracturetectonic origin. A wide use of aero- and space images combined with scrupulous field research demonstrated paragenetic connection of ice exaration relief with neotectonic fractures, with zones of modern tectonic activation. The collected data can be summed up in the conclusions made by $\mathrm{V}$. G. Chuvardinsky [3-5].

1. Crystal foundation of the eastern part of the Baltic shield is divided by a dense network of neotectonic fissures, among which one can distinguish deep, regional and near-surface fractures: sidethrusts, up-thrusts, down-thrusts, over-thrusts and thrusts-apart (Fig. 2).

2. The systems of deep and regional neotectonic fractures and large "ice exaration" forms of relief (such as fjords, skerries and lake kettles in the crystal rocks) establish united parageneses. These types of "ice exaration" relief are a geomorphological expression of fracture neoformation and neotectonic dislocation along fractures under the conditions when the Precambrian crystal shield undergoes horizontal tectonic compression.

3. There is also a connection between smaller "ice exaration" types of relief (sheepbacks, curly rocks, rock polishing, systems of furrows and striae) with such structures as over-, up-, down- and side-thrusts. Massive occurrence of these forms of relief is observed at the ends of large shifts, and they are essentially dislocators and slickensides of the above-mentioned fracture structures - especially, near-surface over-thrusts and numerous spalling spots, whose dislocated elements were crushed into small-boulder material and then gravitationally displaced to the bases of the hill slopes.

The fracture-tectonic genesis of these structures is additionally confirmed by the following data:

1. It can be seen in the contour of large outcrops of crystal rocks that polished and striated slopes of sheepbacks and curly rocks sink under the upper walls of over-thrusts, up-thrusts and flat down-thrusts. The polished and striated rocks sink deep into other rocks and have an evident fracturetectonic genesis (Fig. 3 and 4).

2. Gravitational sliding of rock blocks in intrusive massifs leads to massive outcrop of polished surfaces of typical sheepbacks of intrablock origin (Fig. 5).

3. The slickenside of sheepbacks is covered with a film of mylonitized rocks, and the systems of furrows and striae go in parallel and subparallel, which is typical of tectonic structures.

The largest types of "ice exaration" relief: fjords, lake kettles and skerries - are located along the system of regional and deep fractures of crystal foundation. Association of these formations with neotectonic fractures is more evident on space images: their configuration reflects the system of orthogonal fractures. Fjords, skerries, lake kettles are often oriented in four directions: they have abrupt elbow bends and cross shapes - they are formed at the sites of intersection of orthogonal fractures. 


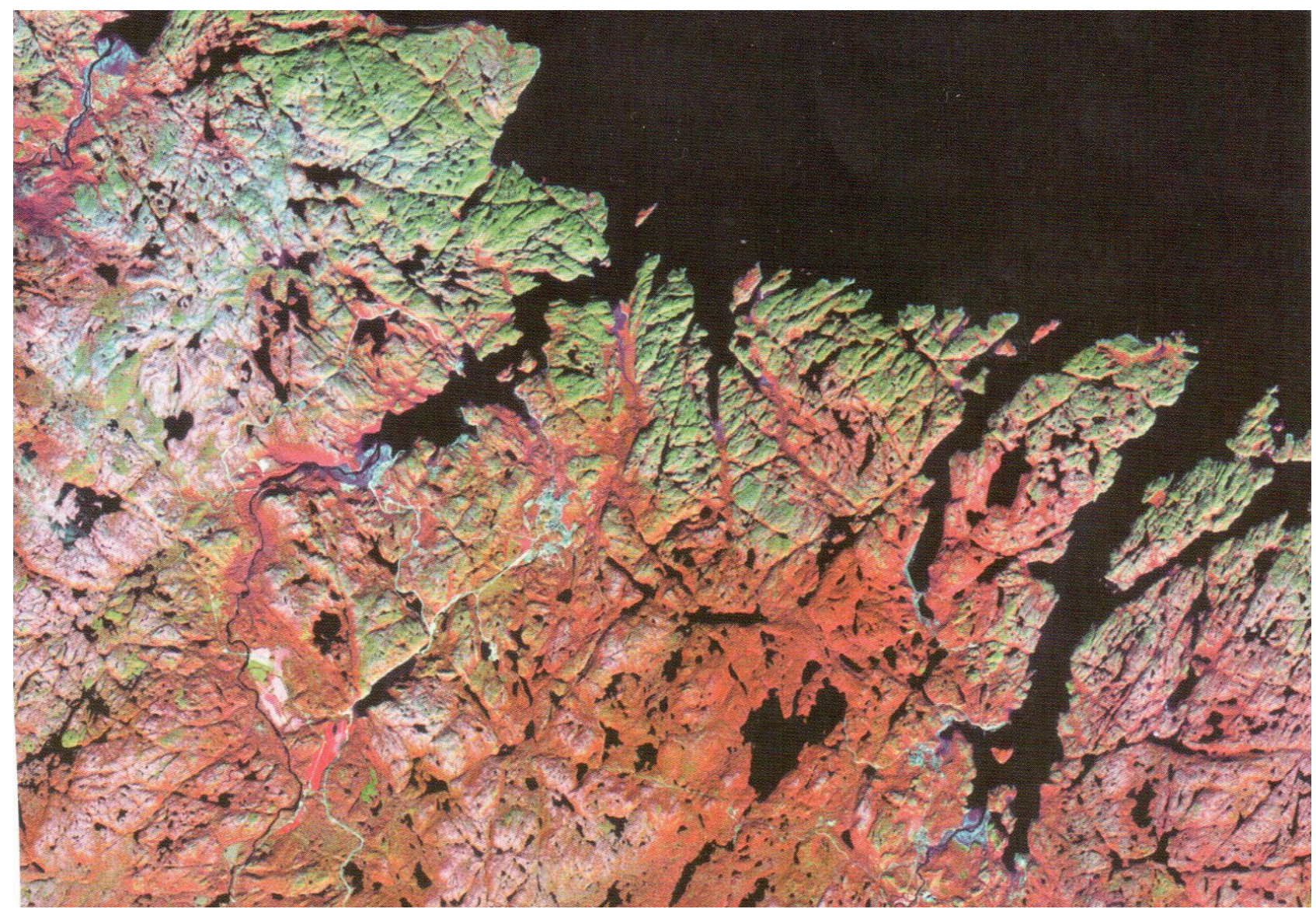

Fig. 2. A space image of the north-eastern part of the Kola Peninsula: the Murmansk geoblock of Archean granitoids divided by a dense network of neotectonic fractures and fissures. The intersecting fractures and fissures form numerous lakes, which are the deepest at the sites of fracture intersection. The coast of the Barents Sea is complicated with fracture-tectonic zones, fjords

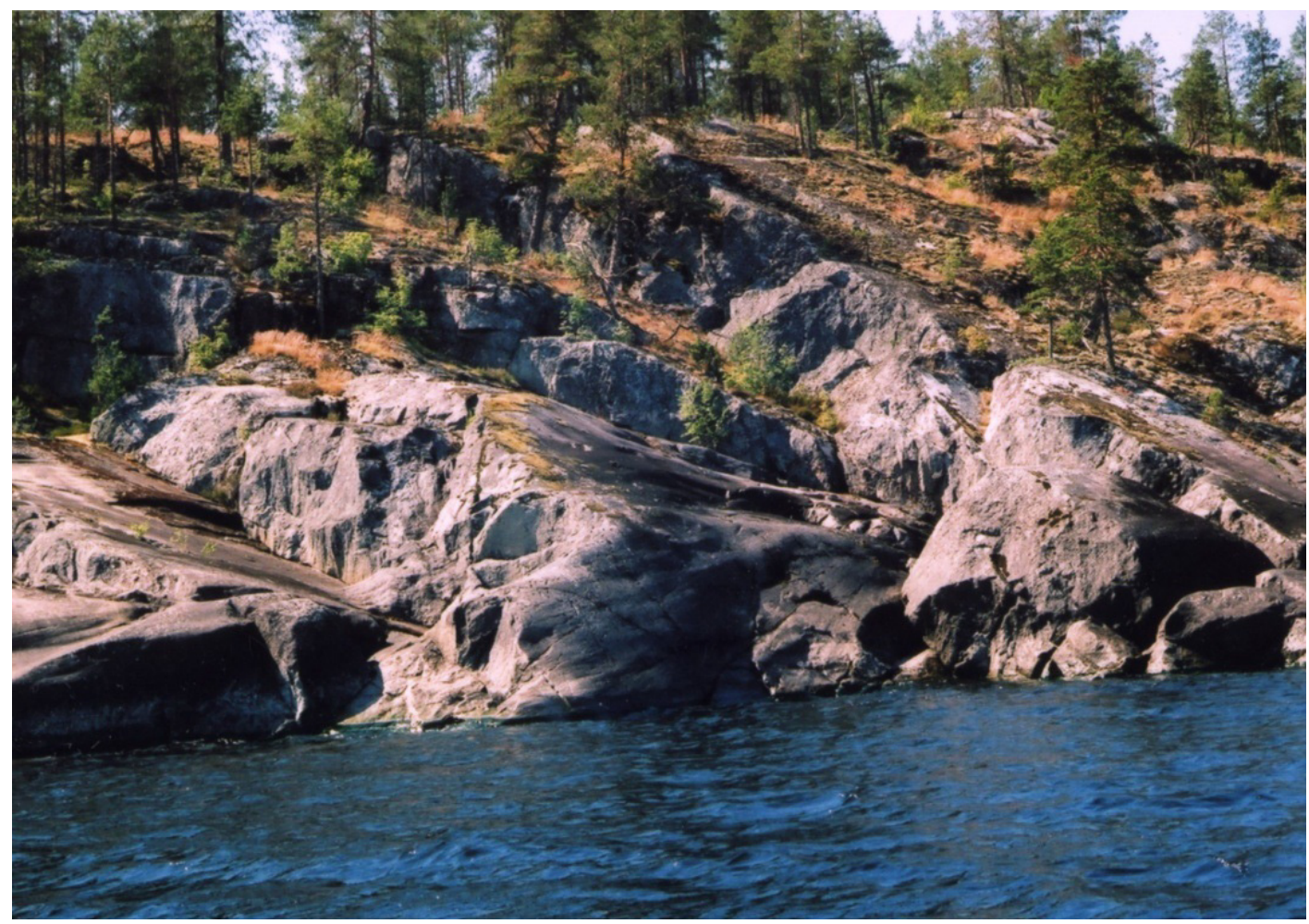

Fig. 3. Neotectonic scale over-thrusts ("curly rocks") in Proterozoic migmatites. One can see sinking of polished and striated slickensides under the adjacent rock blocks; the Island of Putsaari, northern part of the Ladoga graben (photo by V. G. Chuvardinsky) 


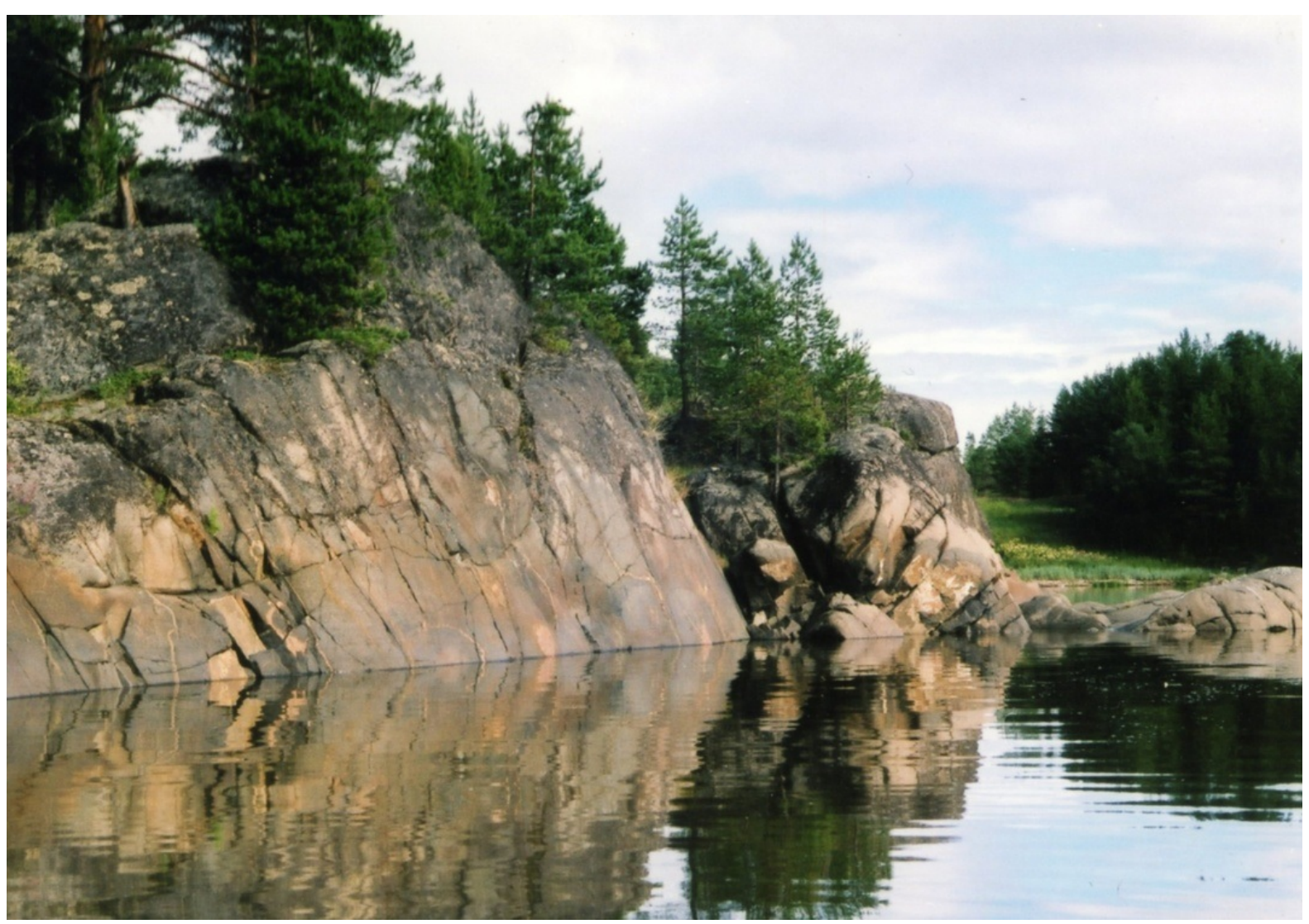

Fig. 4. Slickenside of a side-thrust: a general view of the arched side-thrust and the zone of tectonic crushing in gabbro-norites. The Ovechy Island, Kandalaksha Bay (photo by V. G. Chuvardinsky)

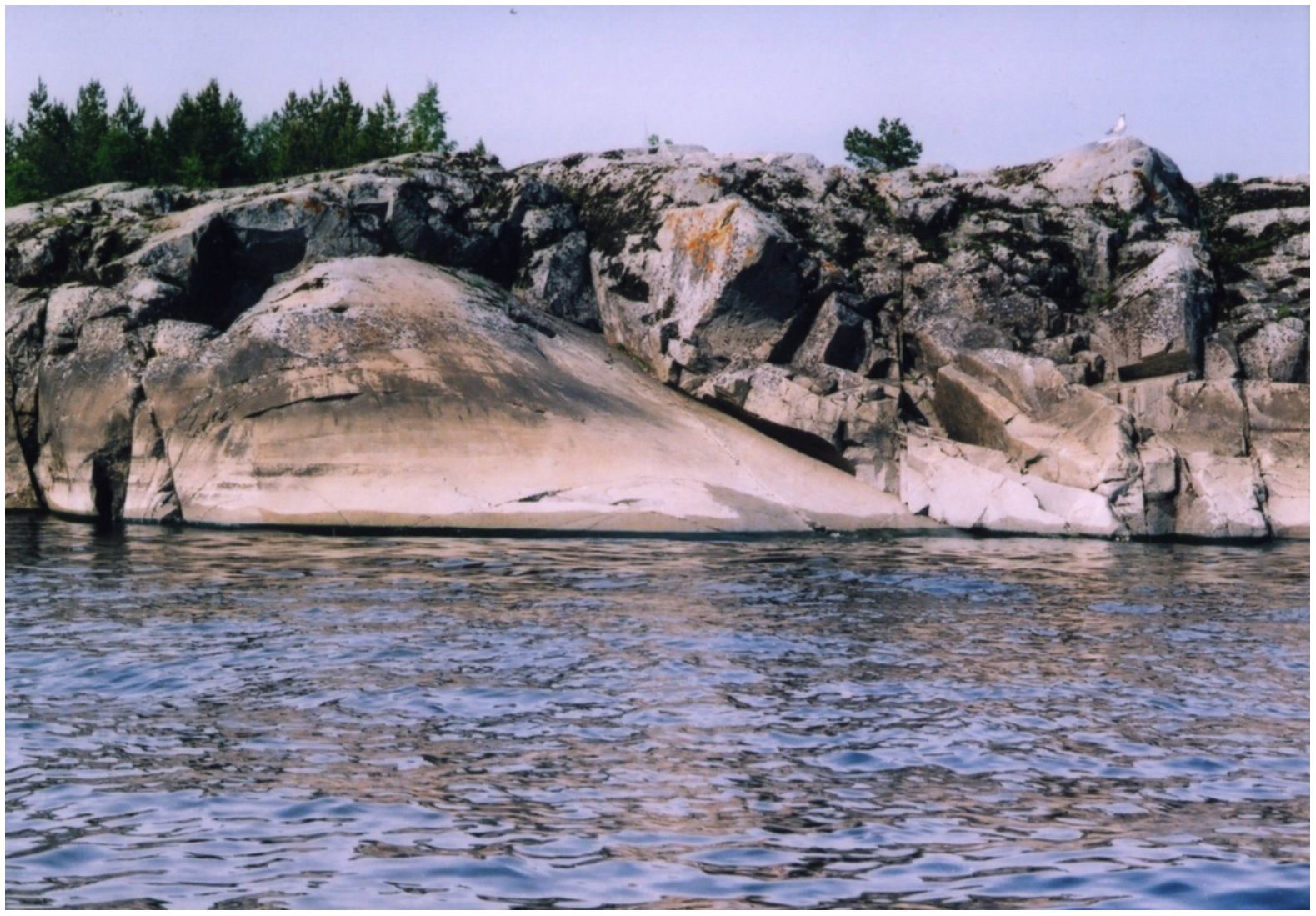

Fig. 5. Tectonic formation of sheepbacks on grandiorites. In the process of gravitational sliding of rock blocks, spherical and egg-shaped polished surfaces of intrablock origin come out. The development of sheepbacks of this type is related to the neotectonic growth of the roof of intrusive rocks (grandiorites). An island near the Cape Impiniemi, Ladoga skerries (photo by V. G. Chuvardinsky) 


\section{Results of glaciological studies}

The scientists from universities and research institutes united in "scientific-glacial" schools constantly refer to glacial covers of the Antarctic and Greenland. In their opinion, it is these covers that carried out colossal tectonic work. They deem the existence of these enormous glaciers as a proof that the glacial theory is true and inviolable; they believe that those glaciers gouged the Baltic shield in the Quaternary, scouring crystal rock strata up to 200 meters thick.

To get at the truth, one has to examine glaciological activity of these ice covers, which have successfully carried out their glacial functions for million years.

By now, glaciologists, geologists, drill specialists and geophysicists have obtained detailed information on the dynamics and specifics of cover glaciers movement - across their entire profile. The results of through drilling of the Antarctic and Greenland ice covers - down to their foundations are of special significance, the results were obtained within the framework of international projects.

A thorough research of multi-kilometer ice columns, study of vertical ice steeps and ice from the tunnels drilled in the foundation of glaciers yielded unexpected results. It turned out that instead of moraine-containing ice strata filled with huge blocks and boulders (which is usually depicted in the textbooks on general/Quaternary geology and geomorphology), the continental ice only contained inclusions of sandy-loam and earthly matter. Even in the near-bottom parts of glaciers - the parts where rich moraine stuffed with huge blocks and iron-shaped boulders is usually drawn [6]. See, for example, V. M. Kotlyakov's and N. V. Koronovsky's schemes and schemes of numerous scientists who were working with these academicians (Fig. 6). The only inclusions found were small lenses, clots of loamy and sandy matter and scarce sand grains. The content of those mineral inclusions is a few hundredth of a percent, and they mainly consist of volcanic ash, microcosmic particles, aeolian dust, rare inclusions of earthly terrigenous matter, as well as spores and pollen [7].

Glaciologists also established that the nearbottom ice strata of cover glaciers (which, according to the glacial theory, should perform all the geological work) are not involved in the general movement of ice masses: they have been lying idle for hundreds of thousands of years, preserving subjacent rocks from denudation and weathering. Moreover, ice covers conserve large paleotectonic lakes with their relict, very ancient water, protecting them from the notorious "gouging".

Thus, contrary to the canons of glacial theory, ice covers do not scour, gouge and pluck subjacent rocks, do not form ice exaration types of relief and do not form various "glacial-tectonic" constructs. They do not include blocks or boulders, and after thawing they can only leave a thin, irregular layer of sandy-loam sediments. That will be the true basic or ground - moraine of ice cover.

How has it been possible to conceal for such a long time that there is no boulder-block morainecontaining strata in the lower (or any other) parts of cover glaciers? The pulverescent earthly matter, traces of which can be found in ice, has been skillfully presented by glacial scientists as near-bottom moraine, and everyone has been convinced of that! Naturally, how else could it be? If the terms "moraine-containing strata", "near-bottom moraine" are used authoritatively and instructively, the glacial strata must contain blocks and boulders. Ice should be stuffed with them, exactly like many schemes and profile pictures illustrate! The glacial theory was advocated by Evteev's opinion and other proponents. For half a century they have thrown glacial dust in everyone's eyes.

One cannot help but remember Hans C. Andersen's tale "The Emperor's New Clothes" (1843). In the tale, chamberlains and other courtiers skillfully ignored the absence of any clothes on the emperor's body and praised the "new garments invisible to commoners" to the skies. And here we have followers of the glacial theory, who have been zealously singing praises to moraine-containing strata of the Antarctic and Greenland glacial covers and ice caps of arctic islands for decades. This is the real moraine ice, they say, the real "ironboulderous" ice!

That is how they magically transformed a mere volcanic ash and rare terrigenous matter.

A field documentation supplemented by photodocumentation is needed. And such documentation was presented. In a fundamental book - in "The Glaciological Dictionary" (1984), an image of moraine-containing ice (image X.19) was published with the following legend: "Layers of morainecontaining ice in the iceberg near the shores of Wilkes Land" (Fig. 7).

Indeed, as can be seen in the profile of the overturned iceberg, there are strips of blackened (contaminated with mineral matter) ice alternating with pure ice. Yet what is this moraine matter? It is clear that this is an earthly matter, with spots where white ice appears through the blackened layers. In literature, such textures are referred to as "dirty ice"; their moraine matter is represented by loamysilt material. No inclusions - even of a grav- 
el/pebble size, not to mention boulders - have been registered so far in the moraine-containing ice of cover glaciers. The large groups of followers of the glacial theory cannot find anything more graphic than this image, but they must understand that upon thawing, such a moraine-containing ice will yield only millimeter-centimeter layers of loamysilt sediment. This sediment is what should be considered the real near-bottom moraine of a cover glacier. But even near bottom parts of rock-valley glacier include no boulders (Fig. 8).

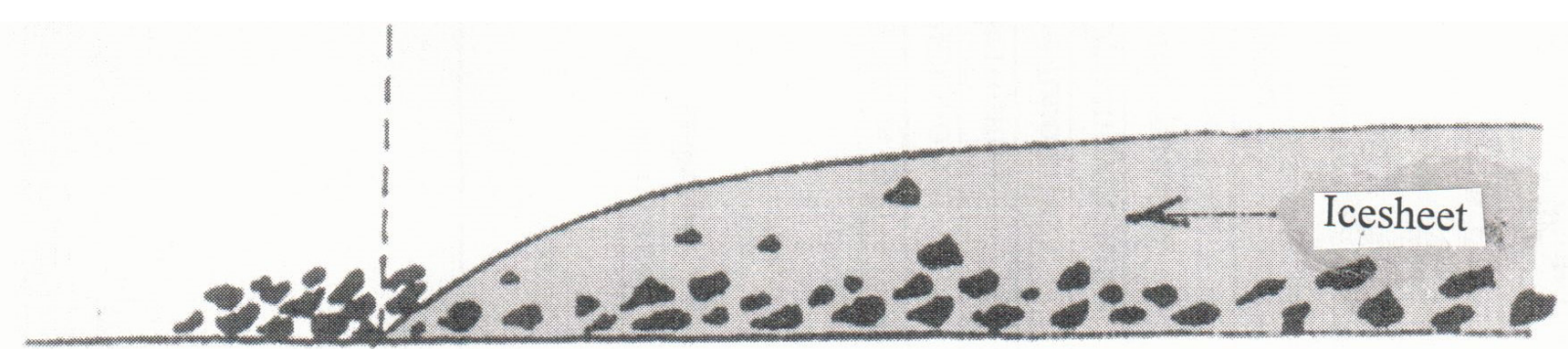

Fig. 6. A generalized model of the Quaternary cover glacier. The most (almost $1 / 3$ of ice thickness) largest-blocked near-bottom moraine (according to N. V. Koronovsky, 2006)

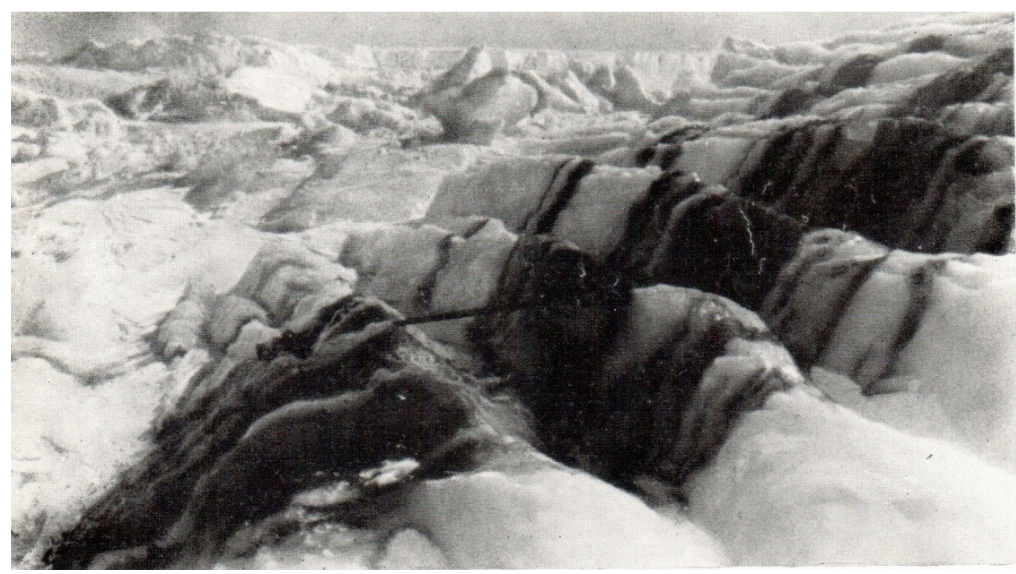

Fig. 7. Layers of moraine-containing ice in the iceberg near the shores of Wilkes Land, the Antarctic (The Glaciological Dictionary, 1984. Image X.19)

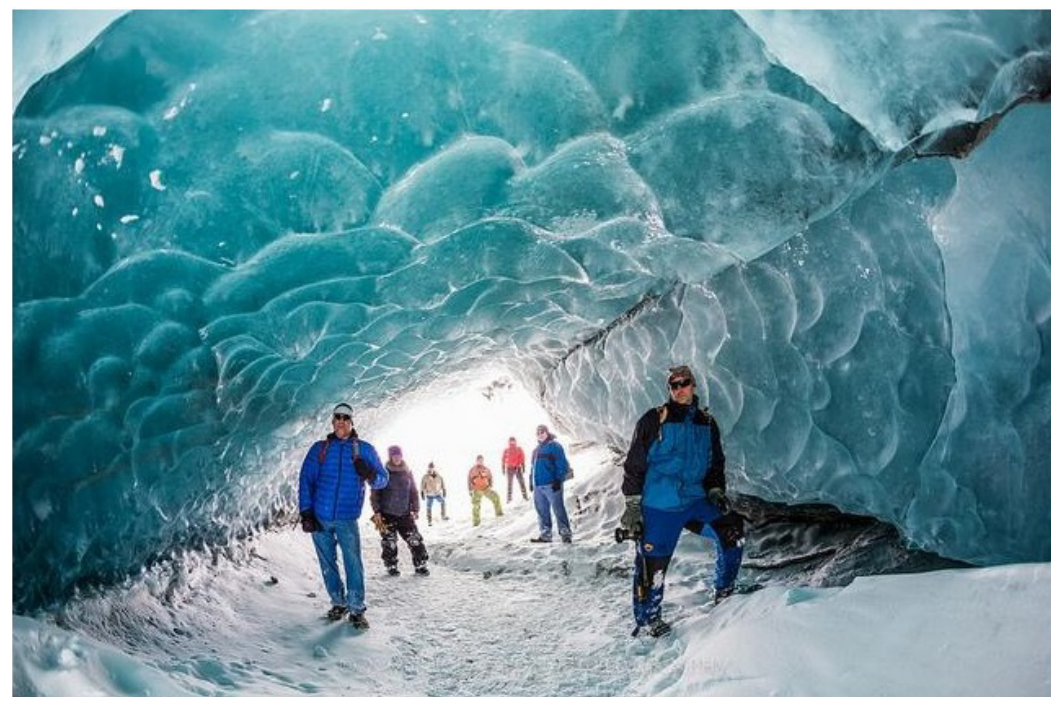

Fig. 8. A natural tunnel in the near-bottom part of the mountain-valley Matanuska glacier, Alaska. The tunnel was made by temporal glacier water streams. In this three-dimensional exposure of ice, no boulders or smaller rock

pieces can be seen: not in the glacier walls, nor in its foundation, nor in the ceiling - nothing is left from the thawed ice, although the outer surface of the glacier does contain large-clastic material fallen on the glacier back from the overhanging hillsides. The photo-documentary material confirms the conclusions made by E. Evenson and J. Clinch [8] who studied the Alaskan glaciers "MacLaren" and "Gulcana" that bottom moraine is completely absent there. Certainly, there is no much published intra-tunnel eskers (image http://www.beshan.com/wpcontent/uploads/2014/05/Matanushka-glacier-panbing.jpg) 


\section{Hypotheses about the causes of glaciations}

The causes of glaciation of the Earth hypothesis have a great history - for some reason scientists express a feeling of solemn satisfaction about its endless amount. Back in 1988, A. V. Lapshin counted more than 200 hypotheses on glaciation causes; the rate of annual increase in the number of hypotheses from 1 to 2 hypotheses per year was also outlined.

Generally these figures have been confirmed by scrupulous calculations of N. M. Chumakov [1] and they even increased: "In the middle of the last century, M. Schwarzbach counted at least 70 hypotheses on glaciations causes. So far, the number of such hypotheses has increased by several (!) times" - Chumakov writes proudly, but at the same time complains that "it is impossible to consider the problem of glaciation cause in one project" with such a scope of hypothetical work.

So what will we do? Create a scientific research institute of glacial hypotheses on the budgetary basis? Dear scientists! It may be worthwhile to think about the conception of English geologist J. Charlesworth who analyzed many hypotheses on the causes of the ice ages and came to the conclusion that they "vary from improbable to internal contradictory and clearly imperfect". The situation has become completely complicated, but scientists cannot refute the glacial theory, which has become the religion long ago.

\section{Erratic boulders and "glacial beds" of Late Paleozoic "glaciation"}

The processes of fault-tectonic breaking and fragmentation of crystalline Precambrian rocks took place in the Paleozoic, Mesozoic, and Cenozoic. They were accompanied by a partial lengthwise fault movement of blocks and boulders. The most precise indication of the lengthwise fault transport of tectonic breccias material (friction breccias) are the blocks and boulders carrying scars, striation, furrows and its faces polishing.

Despite the claims about the extraordinary thickness of the Permo-Carboniferous glaciation, the composition of boulders attributed to this glaciation has been studied poorly - the only exception is the works of A. du Toit [9].

But the boulders of the Quaternary system have been thoroughly studied, and detailed boulder surveys were conducted on the Baltic Shield and Putorana Plateau with the discovery of ore deposits among the ore boulders [10-12].

\section{The origin of the tillites - "indicators of glaciation"}

Over the past decades, many geologists and tectonists have obtained solid data showing that the tillites are of tectonic origin. One group of these formations belongs to the olistostromic formation, the other - to the tectonic melange (tectonic massif, tectonic breccias). The tectonic origin of the tillites in our country was proved by many researchers: N. N. Kopylova, V. Z. Negrutsa, A. A. Predovsky, A. V. Volin and many other researchers.

What are the tillites? According to the "Geological Dictionary" (1973) tillites ("ancient moraines") are unsorted deposits subjected to thickening, sometimes metamorphism. They are formed by a fine-grained mass, which includes boulders and other coarse clastic material of different size and composition. The lack of stratification and the presence of boulders with striation are typical for the tillites. So, the ice sheet "moved", cut and plowed crystal rocks, crushed them into blocks and boulders, furrowed and polished the bedrock. And it also detached huge (a few kilometers across) erratic masses and moved them up to $500-700 \mathrm{~km}$. Many Soviet-Russian and foreign scientific schools madly insist on these actions of ice sheet. Scientists diligently conceal the results of drilling the Antarctic and Greenland shields that convincingly prove the complete absence of boulders or smaller debris in glaciers mass. There are only dust-like inclusions - mostly volcanic ash. In addition, it is established that the lower layers of glacier are immobilized; their function is to conserve geological preglacial surface.

At the same time, field geologists repeatedly traced the transitions of the tillite strata to the crushed rocks, and then to the monolithic bedrock in outcrops and drilling sections. However, tectonic slickensides with striation and furrows were fixed on both block-boulder material and monolithic rocks. The researchers drew the following conclusion: the tillites are typical tectonic (fault and near-fault) friction breccia. In large (regional) fault systems the friction breccia reaches a depth of tens and hundreds of meters. An explanation is also found for such an argument of proponents of tillites glacial genesis as the presence of alien, erratic blocks and boulders in them. The works of the above-mentioned researchers and a number of other researchers have indicated that the tectonic shift of coarse clastic material in melange and tectonic mass reaches tens, sometimes hundreds of kilometers. Therefore it's no coincidence, as it is now specified, that the classical Permo-Carboniferous tillites of the Dwyka series were formed in isolated 
tectonic depressions and fault trough, where their thickness (together with the olistostrome) reaches 300 and even 500 meters. Moreover, the furrowed, striated bedrock is the tectonic slickensides. The thickness association of the Permo-Carboniferous tillies to the largest fault-tectonic zones active in this period is repeatedly emphasized in the book "Winters on our planet" [2].

The establishment of tectonic genesis of the former Paleozoic tillites thicknesses and younger tillites (melange, tectonic mass, and mixtites) is of important paleogeographic significance. But the revision of the Permo-Carboniferous tillites genesis is taboo (otherwise the whole proof system of the giant glaciation will collapse). Scientists rely on "glacial" boulders, on striation and scars on them, on faces polishing, tuning out the fact that these are the most reliable indicators of tectonicmechanical processing of blocks and boulders as the part of friction breccias.

As for the polished and furrowed "ice bed" of bedrock, as well as roche moutonnée and fleecy rocks, associated with the tillites, it is also a clear evidence for the tectonic near-subsurface shear shifting of fault and thrust types. This may close the topic about massive Permo-Carboniferous glaciation. Tectonic landslide and talus deposits (olistostromes) are located in the paragenesis with tectonic tillites and they often form thicker strata of boulder mixtites, which are also taken for moraines (thillites).

Long ago geologists-tectonists have established the coincidence of "glaciations" with the restructuring of the tectonic plan of the Earth, with the periods of orogeny and rift genesis, which finds its natural explanation, if we consider that the tillites strata is the indicator of global tectonic processes. As for the Late Paleozoic ice age, the recognition of the tillites tectonic genesis and the fault-tectonic origin of the exaltation relief will make it possible to get rid of the obvious inconsistence and contradictions caused by the need to combine the theory of super ice sheets with warm and humid climate of the Carbonic period and arid hot climate of the Permian one, environmental conditions that really existed on vast areas of land.

One more conclusion is the following. The formation of tillites (melange, mixtites) does not depend on climatic zones of the Earth and can occur both at the equator and at the pole - everything depends on the tectonic processes and their intensity.

\section{Hindustan plateau Deccan and Erratic boulders}

But nevertheless, there are sometimes interesting facts concerning erratic boulders in the Paleo- zoic arises. First of all, this refers to the Deccan plateau, which occupies almost half of the territory of Hindustan. This famous plateau is thoroughly described in the book of M. S. Krishnan "Geology of India and Burma" [13].

The Deccan plateau is composed of a mass of effusive Deccan trappean - volcanic basalt lava. In the west of Hindustan the thickness of the trap mass reaches $2 \mathrm{~km}$ and gradually decreases in the east to several hundred meters, and then tens of meters. In general, the Trappean Plateau has a graded surface, creating the large mountainous relief forms in the west of Hindustan - the Western Ghats with the height of more than $2 \mathrm{~km}$.

What is the geological age of this trappeanbasalt formation? When did such a powerful fissure lava outflow occur? Indian, English and other geologists unanimously refer this formation to the late Mesozoic, to the Cretaceous period. The reader should pay attention to this fact, since it is of decisive importance for clarifying the nature of the erratic boulders - gneisses and granites lying on the surface of the traps.

A scheme of the Permo-Carboniferous glaciation of India was presented in the book "Winters on our planet" - collective work of authors B. John, E. Derbisher, G. Young, R. Fairbridge, J. Andrews [2]. In the scheme and in the text of the book the authors point out the presence of erratic boulders of the bedrock rocks on the trappean plateau Deccan (gneisses and granites) that the glacier has brought and scattered. They even write about "glacial beds" - polished and striated by that "glacier" of the bedrock on the same plateau Deccan. Where did the ice sheet bring these boulders from? B. John and co-authors explain: Erratic boulders were brought by the glacier, it captured them on the bottom of the Indian Ocean, and maybe even on Madagascar. The glacial path is indicated by long, thick arrows on the authors' scheme.

Wasn't it facile for the famous scientists to hurry up to move the Permo-Carboniferous glacier from the bottom of the Indian Ocean and unload the boulders onto the lava (trappean) Plateau of Deccan, which geological age is late Mesozoic?

Lava flows hadn't formed a plateau yet, but the glacier had (a whole geological period forward) already provided the plateau beforehand, not arisen yet, with erratic Archaean-Proterozoic boulders. Or the Gondwana glacier in some other way brought the boulders and somehow, after the end of lava flows eruption, dropped them on the frozen lava?

Do you remember the reprise of Arkady Raikin: "Our people are being fooled - our sawdust is inside the armor of the medieval knight!" So we can't help but mention the Quaternary glaciation (though as mythical as the Late Paleozoic). 
The Quaternary glacier hypothetically can cover with its boulders rocks and deposits of any geological formation from the Archaean to the Pleistocene. Only the Holocene is not subjected to it (although furrows, striation and rocks polishing, as well as blocks and boulders are also being formed in the Holocene - for example, in Kandalaksha and Ladoga graben - fault tectonics continues to act).

Regarding the "great Late Paleozoic glaciation," it is necessary to keep watching its traces that are not found on the rocks of younger formations.

\section{"Glacial bed" on the plateau of Deccan}

In the same book, "Winters on our planet," a team of foreign scientists placed an expressive $b / w$ photo of a furrowed "glacial bed" on the surface of the same Deccan plateau. The inscription under the photograph runs: "The smoothed, striated surface of the bedrock (a glacial bed) in Irai (Central India). The direction of ice movement in the Permian-Carboniferous period is clearly visible".

Indeed striations and furrows can be seen quite clearly, the authors skillfully subdued the ice movement to the striation stretch, but did not indicate the main thing - the geological-petrographic name of the rock "furrowed by glacier". If their purpose was to save paper, then it was reasonable to replace the term "bedrock" with a simple name for the rock - such as basalt or trap. In this case they get both "saving" and clearer geological age of the "bedrock". It would be good to indicate the exact location of the unique outcrop for India (in our archaean rocks of the Northern Ladoga such furrowed rocks are traced continuously). And the team of authors avoids the most obligatory thing for the geologist - to name the rock and give the location of the outcrops - and in fact the Hindustan glaciation system is kept on this single photograph, on this lonely "glacier bed".

Since it is not always possible to determine the rock on $\mathrm{a} b / \mathrm{w}$ photograph, I will try to deliver indirect data. On the geographical map, the place Irai (where the photo was taken) could not be found - a large-scale map is needed, but according to M. S. Krishnan [13] Central Hindustan - the Deccan plateau - is composed of trappean-basalts, in which there is intertrappean interbed, also Mesozoic, of gray limestone and siliceous rocks. If the "bedrock" is the trappean-basalts or the intertrappean interbed, then the striations and furrows are brought onto them after the lava flows cooling - it means it can be both late Mesozoic and Cenozoic neotectonic. So the "glacial bed" is not recent, but the post-Paleozoic glacier did not "cover" it.

As for the erratic boulders on the surface of the Deccan trappean, they are derived along the faults from the Archaean-Proterozoic basement, overlaid by the traps strata. Like the boulders from a tectonic breccia, they appeared on a plateau or at the end of the Mesozoic or in the Cenozoic. In the southern part of India and in Ceylon, where the Archaean-Proterozoic crystalline basement comes to the surface, there must be many Quaternary boulders and quaternary striation and polishing of granites and gneisses - neotectonic processes are still actual.

\section{South and Equatorial Africa}

The scheme in the book by A. du Toit [9] depicts the lines of glaciers movements of the PermoCarboniferous ice age. According to the scheme, they moved in four powerful streams from the north to the south - from the Limpopo River to the Southern Ocean - to the oceanic space, where waters of the Atlantic and Indian Ocean collide (Fig. 9). This scheme was included into almost all paleogeographical books and textbooks on historical geology. But in the key monograph of P. Fourmarier [14] it is unexpectedly asserted that "Obviously in Africa the Gondwana glaciation progressively came from the south to the north, reaching the equatorial zone" (p. 155). Ice sheets, on the contrary, moved to the north from the Limpopo River towards the equator, where the Carrus glacial formation is widely developed in the basin of the Congo River, and strata of the tillites in its composition, that is confirmed by the studies of A. H. Kagarmanov [15] (Fig. 10).

Hoping for the striation on the bedrock, A. du Toit leads the glacier in the southern general direction, to the Southern Ocean, but even if we consider the striations to be glacial, we must take this fact into account - the beginning of the striations and their ending is not distinguishable. We need to identify roche moutonnée - their polished and stiated roche moutonnée exactly indicates, where tectonic pressure and tectonic shearing of the crystalline rocks came from.

Africa has little expressive sheepback rocks or roche moutonnée (not as we have at the Baltic shelf). Hence, trace studies of the vast areas are required in order to determine a vector of tectonic shifts.

Since the Limpopo River has become known even in the US Congress, it would be welcome to organize an expedition to the South Africa to unravel the mystery of the "glacial" period or at least to determine in what direction the round stones moved - to the South from Limpopo or to the North from it, towards the Equator, as P. Fourmarier considers [14]. 


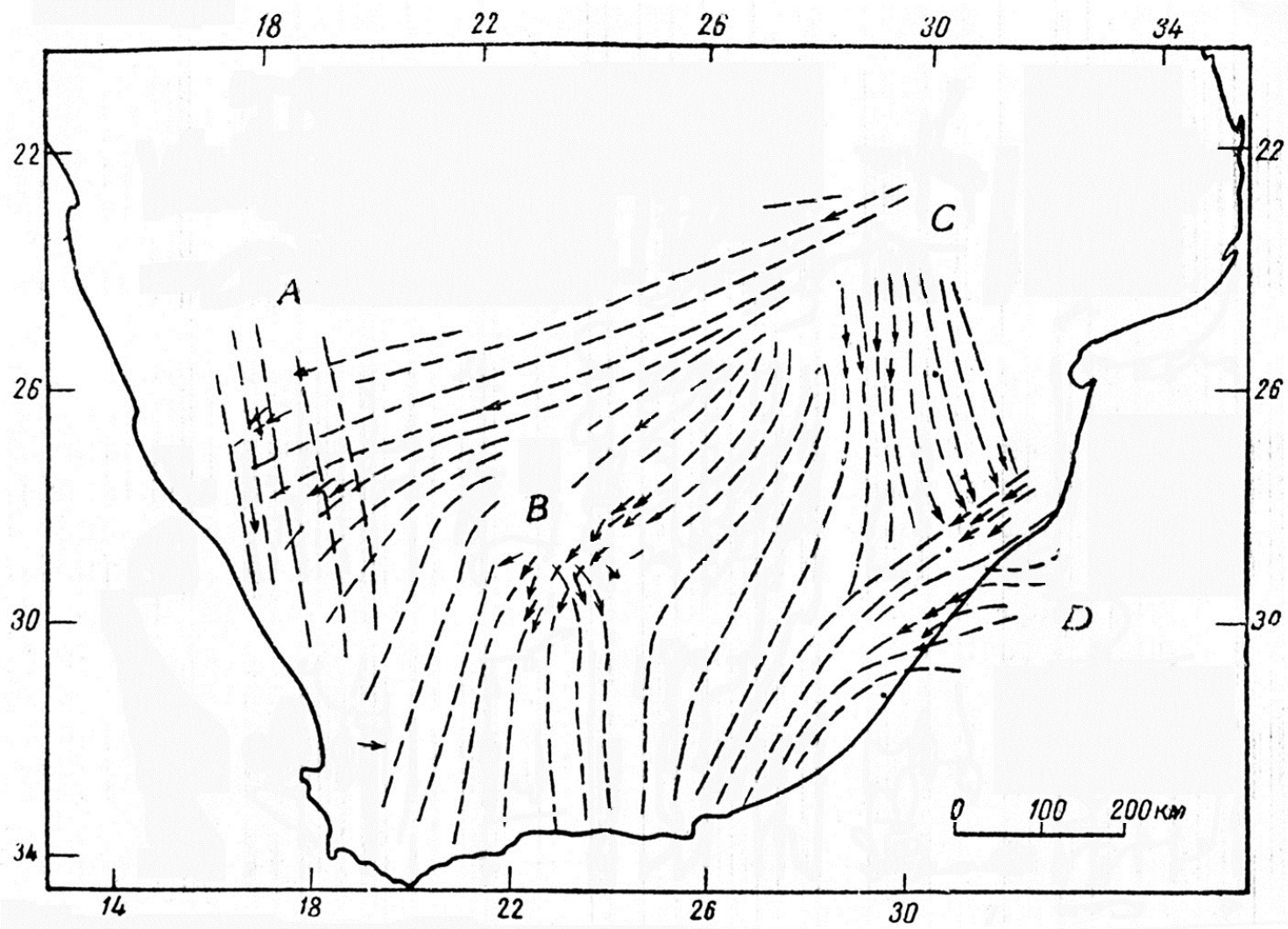

Fig. 9. The direction of the glacial movement in the South Africa (according to A. du Toit [9]). Glaciation sites: A - Namaland; B - Griqualand; C - Transvaal; D - Natal

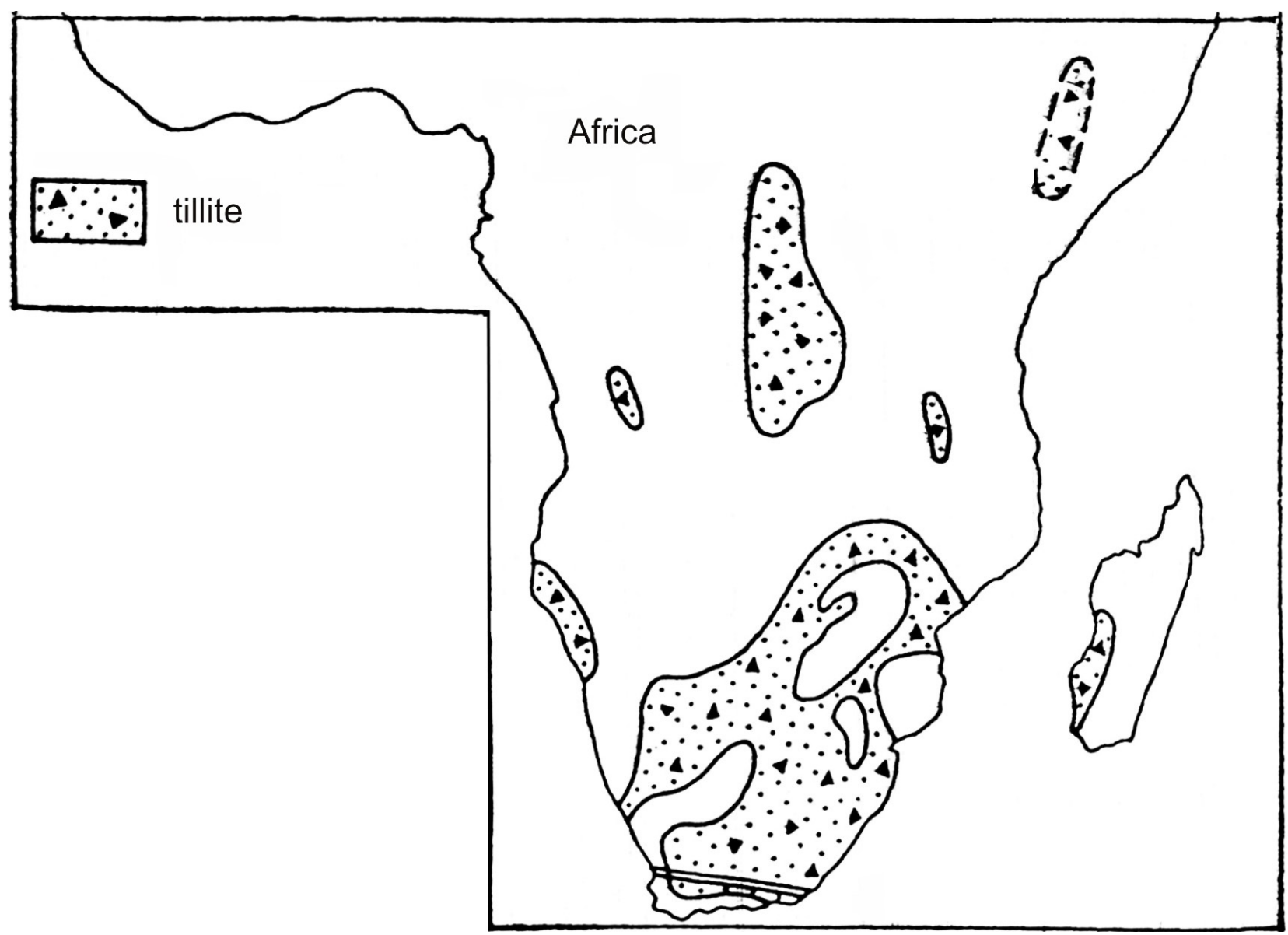

Fig. 10. The scheme spreading tillites of Permian-Carboniferous period of the South and Equatorial Africa (according to A. H. Kagarmanov, 1987) 


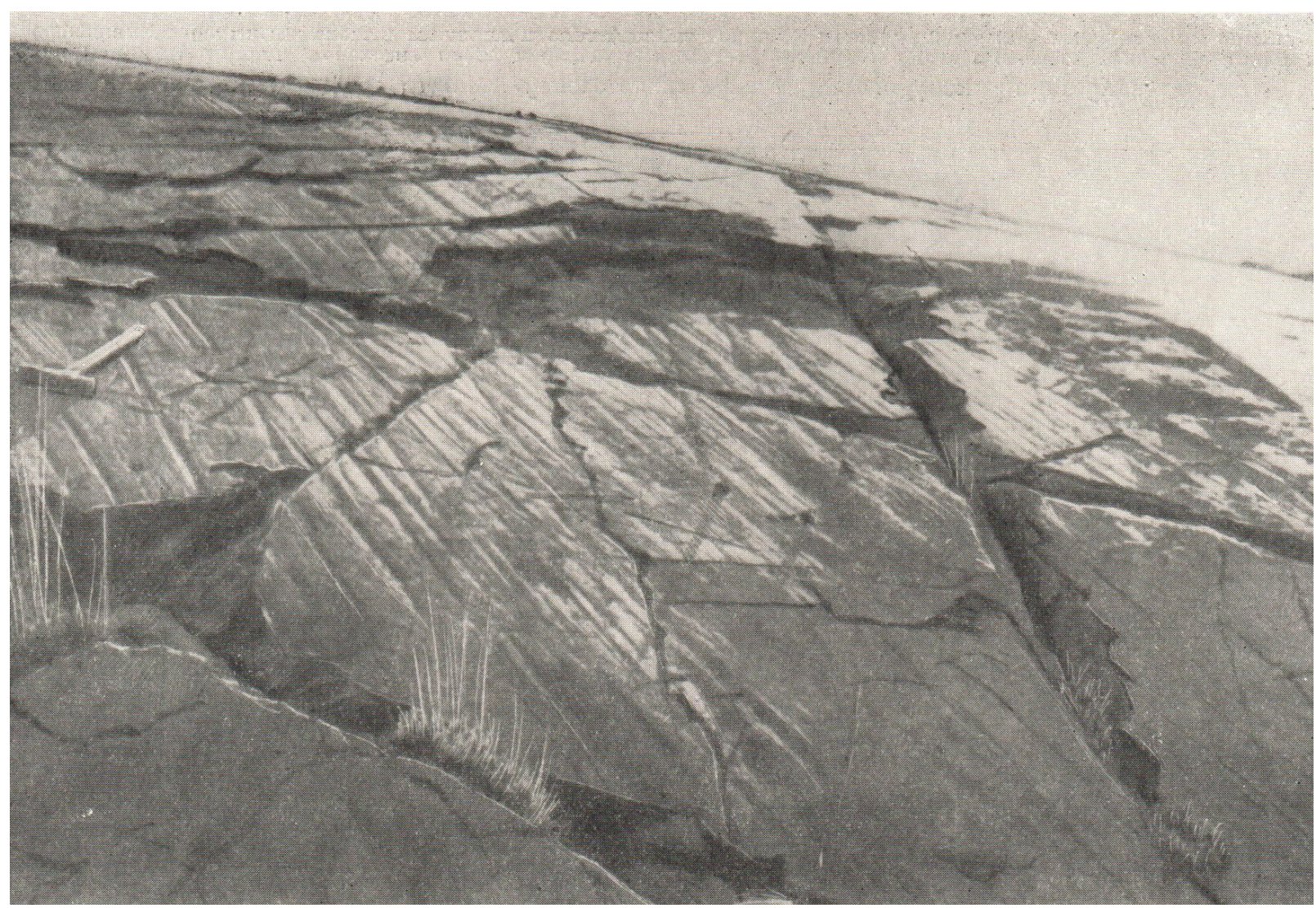

Fig. 11. "Treated by the Glacier" the surface of dolerite-diabase (ice dressed rocks), Noitgedacht, Kimberly country (according to A. du Toit [9])

There is another discrepancy in the glacial plotting: in the scheme of A. Du Toit striae and lines of the glaciers' current are made just on the younger rocks. It is not clear: whether Paleosoil Ice crushed mezoic rocks or to this issue - the lines of ice current- the researches attached relative emphasis. We ask this question when "Geological Map of the South Africa" is overlapped with the scheme spotted with quasi visible and inevitable traces of movement of the glacial currents. Why these "inevitably visible" traces are mapped and laid along the large area of the development of powerful effusive basalt strata forming the Dragon Mountains? These effusive strata are of Jurassic age, they did not have time to be under supercover Late Paleozoic Ice, multiple lava cracked effusions missed to meet with the glacier and it remained unknown who won- ice or fire. Yet, according to the scheme, we have triumphant travel of the glacier, the glacial theory is in comfort with erratic boulders laying on the Jurassic lava basalt rocks of the Dragon Mountains which are younger then the glacier as on trappean plato Dekkan. Since the boulders are erratic, then according to the Glacier Theory, they can be only glacial, and then Jurassic lava basalts should be announced as Devon or Jurassic glaciation has to be introduced!

"Age" problems are also available with African striae and grooves. Along with striae on Archei-
Proterozoic rocks there are scratches and grooves on intrusive sills of diabases and dolerites breaking the deposits of Gondvan "glacial" series. And no questions would arise if these striae and fault trace rifts are considered as tectonic, and not glacial. Since the researchers write again about "glacial beds" we have to remind that these "beds" and striae on them could not be formed by Late Paleozoic Glacier: diabases and dolerites sills broke "glacial" Karry series after the Glacier in Jurassic period. And may be the activists of the Glacier Theory will organize Jurassic oscillation of the Glacier?

There are some other inconsistencies. The book of A. du Toit and famous climatologist Martin Schwarzbach has a photo of the highly cited and reprinted in the literature grooved rock surface in the valley of the river Vaal. There is inscription under the photo made by A. du Toit [9] "Treated by the Glacier the surface of dolerite-diabase (ice dressed rocks), Noitgedacht, Kimberly country." The same exposure (in the other perspective) is demonstrated by M. Schwartzbach in the book "Rare monuments of Nature". There is inscription under his photo: "Ice-worn Permo-carboniferous rock in Noitgedacht. Scratched and grounded by the Glacier the rock was formed with Precambrian lava". Who is right? A. du Toit writes on the glacier treated "the surface of dolerite-diabase", the intrusive rock, laying sillas of dolerite-diabase and 
being of Mezozoic age, and M. Schwarzbach, the same intrusive dolerite -diabase names effusive lava, placing it into Precambrian age!

There are many laboratories in the West which could determine an absolute age of the rock of this world-known exposure, but nobody hurries to do it, the "glacial bed" is so attractive!

In the basin of the Congo River, in its eastern part, striae on the parent rocks are well known.
The authors of these statements, N. A. Butakov, G. N. Leonov, P. Fourmarier do not announce the age of these rocks and even do not give them geological-petrographic name. And the sheepback rocks in Nigeria did not "hide their age". Jurassic intrusive granites form big sheepback rocks. They formed not before Jurassic period and possibly they are of Cenozoic age (Fig. 12).

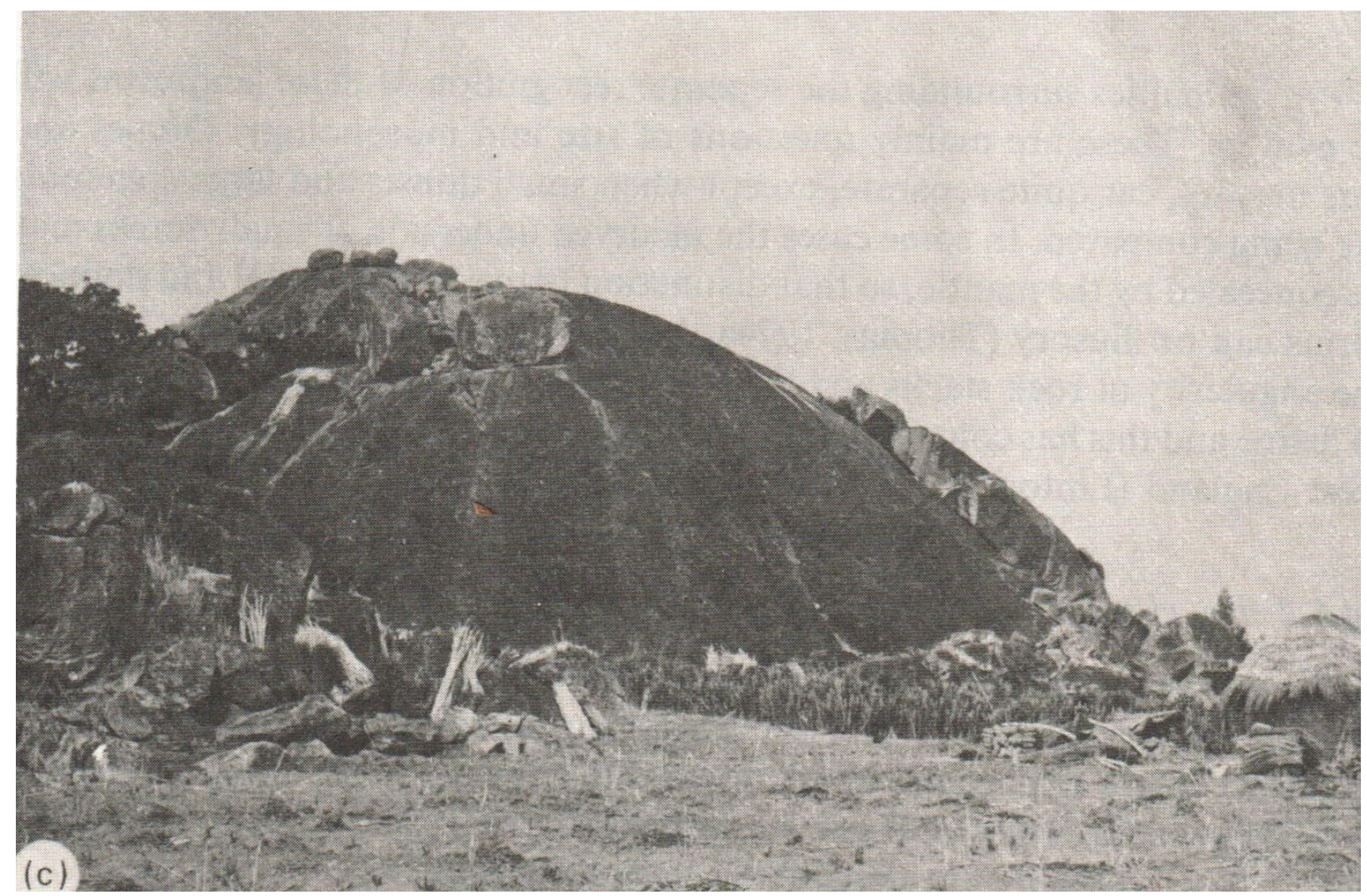

Fig. 12. "Exaration non-glacial type" of relief. Polished surfaces of sheepbacks of fault origin (the sheets were moved by the gravitational sliding) on Jurassic granite in Nigeria (compare with the hut at lower right corner) ("Geomorphology", 1976). These sheepbacks could not be attributed to the Permian-Carboniferous glaciation, granites are of Jurassic age

However, usually the researchers use the term "bedrock" and hence, the so-called striae, grooves and "glacial beds" are as safe as houses. So try to disprove the Glacier Theory! Additionally to this Section we are presenting Neotectonic striae and the scratching of Holocenic (Postglacier) age on gabbro-norites in Kandalaksha trough, on the Baltic shelf (Fig. 13, 14).

\section{Australia}

M. Schwarzbach [16] relates striation of bed rocks, revealed in Australia, to the bright traces of Permian-Carboniferous glaciation, almost the only "glacial" formation of such type on this continent. Famous Glacier Rock Tea House is on this flattened exposure. But the name of the rock is again confidential, and hence the age of striae and their nature is unknown.

\section{South America}

In the South America, in Argentina, with its "glacial" striation and "glacial beds", we have got informative incident. Here how D. V. Nalivkin [17] tells about it. The article of A. Keidel and A. Harrington speaks on sensational discovery of "real" traces of the $4^{\text {th }}$ glaciations in Permocarboniferous period in Argentina. The base was strata of tillites, from 5 up to $6.5 \mathrm{~m}$ depth, separated with layers of sandstones on the 4 th beds. The striated flat areas were also revealed.

S. O. Dunbar, one of the famous American geologists and stratigraphers [18], took interest in this article and interpreted the heart of the matter. Studied the fault tectonics of the area of tillites exposure Dunbar came to the conclusion that striaed and ground flat areas were not the bed of the Glacier, but tectonic polished surfaces. Another "vivid 
glacial evidence" is the presence of four striaed glacial beds in the tillites' section, and, accordingly four "glacial periods" which do not relate to the Glacier. According to Dunbar these formations are also of tectonic origin, being consequence of horizontal deformations of thrust slice type. He marks that all four "glacial beds" are concentrated in the mass of tillites, merely $5-6,5 \mathrm{~m}$ thickness. And in order the Glacier could make striae with separating them layers of sands and gravel rocks, a whole geological epoch is required that these sands could turn into sandstones, and the gravel rocks into gritstones. It is important to understand that no striae are formed on soft deposits.

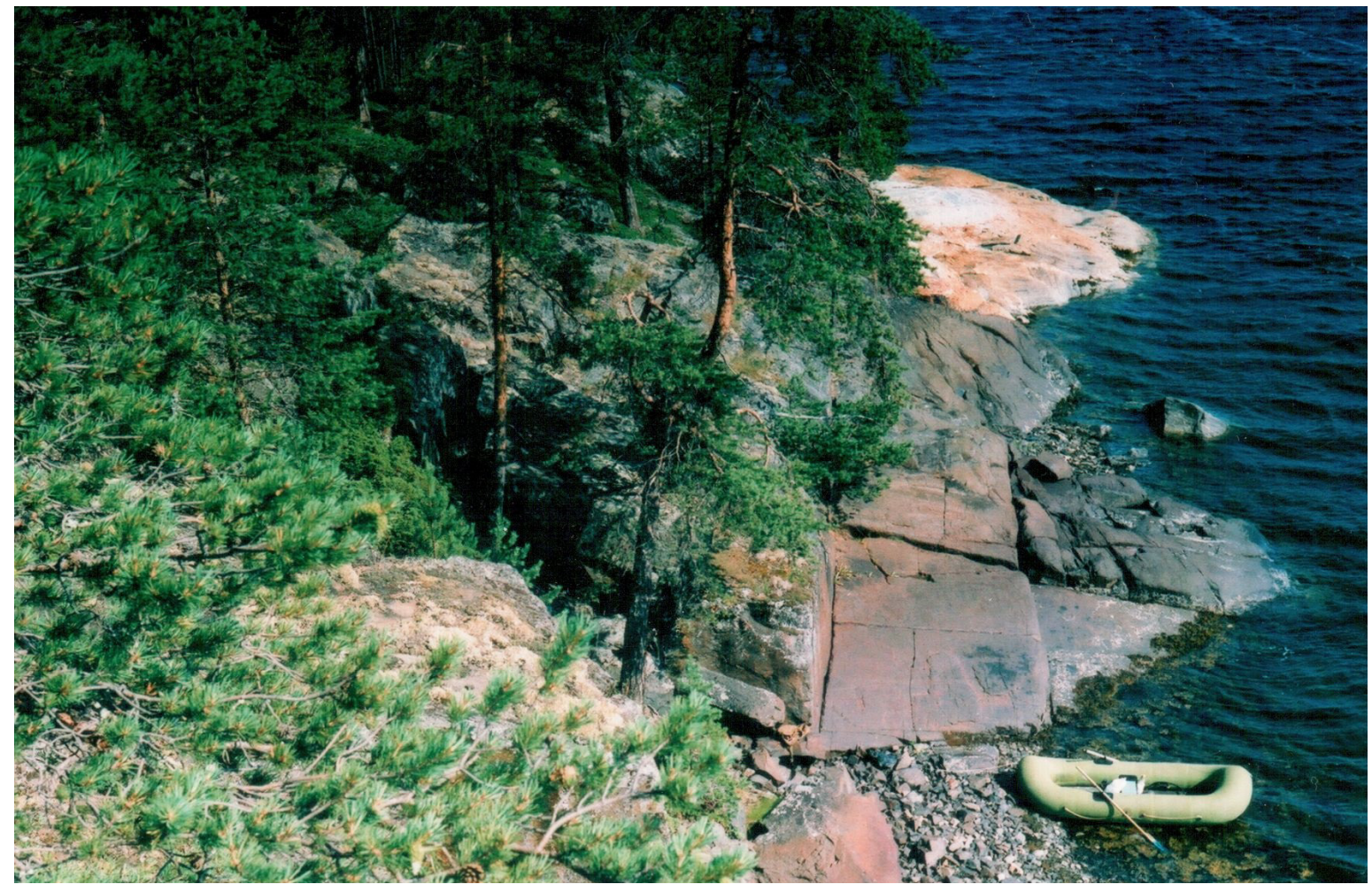

Fig. 13. Over-thrusts coupled with side-thrust. General view in gabbro-norites, island Vysoky (photo by V. Chuvardinsky)

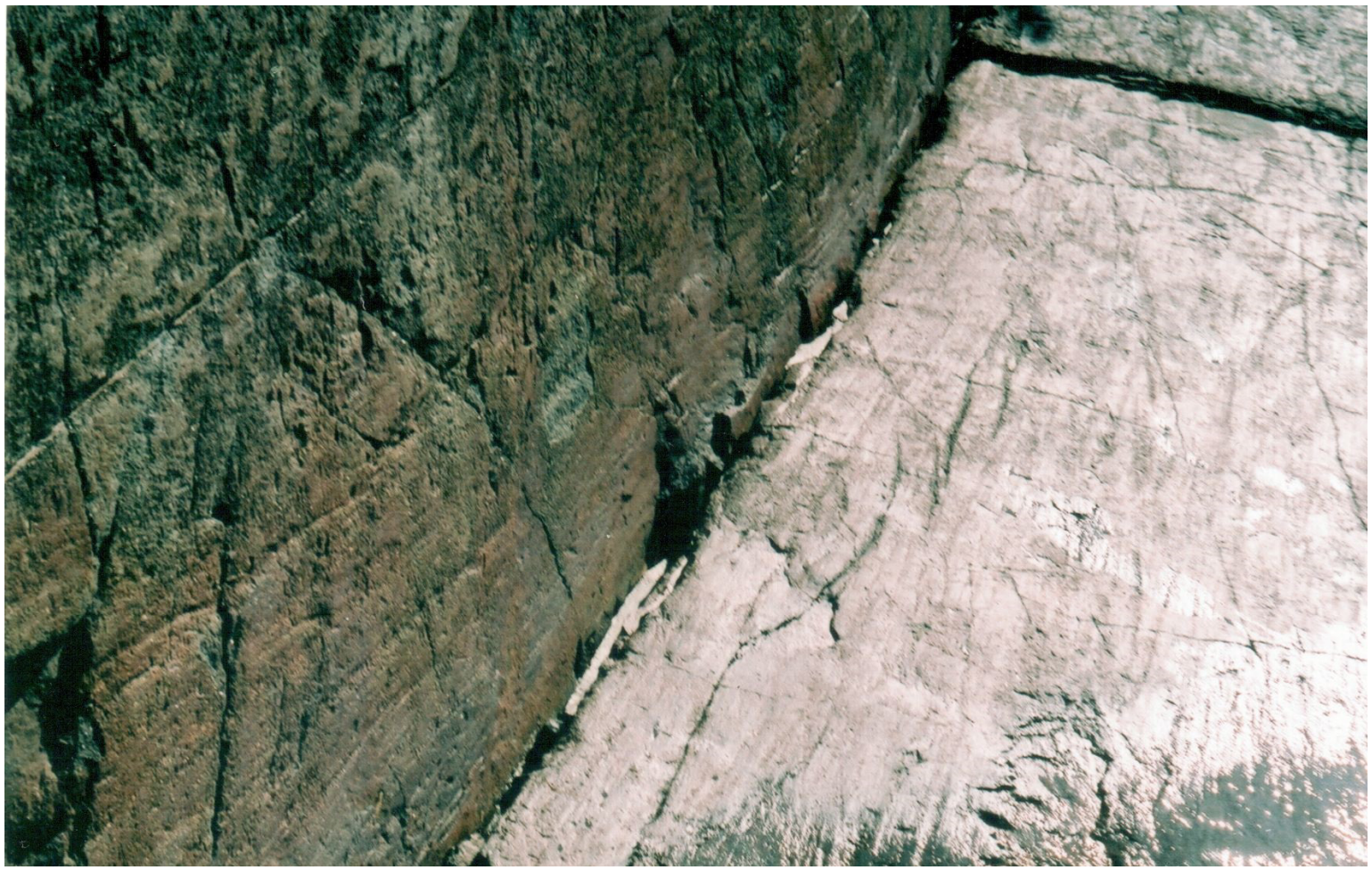

Fig. 14. A structure of slickensides of the overthrust and the coupled side thrust 
A structure depicted in Fig. 13. The surface bears subparallel striae, and furrows, they are developed on vertical and horizontal fault plane. Horizontal trails run depthward to the chop of fault plane. Gabbro-narites on island Vysoky (the North Karelia, Rugozerskay Guba) (photo by V. Chuvardinsky).

If S. O. Dunbar went on, he could shatter the glacial theory of Late Paleozoic period; but he left the work to the other generation, he gave this work to me.

\section{Reference on the origin of furrows and striae}

In ascertaining Permo-Carboniferous glaciation the researches place importance to furrows and striae on bedding rocks and boulders. "Nothing but the Glacier was able to make these forms", they believe. Thus, I shall give information on the origin of these small forms from "Geological glossary" (1973): "Furrows produced by the sliding, unevenness of irregular form, extended in one direction, formed at friction of upland crystallic rocks against fissures surface appearing at tectonic shiftings, for example overthrusts, faults, flaws. They are expressed by the grooves, $2-5 \mathrm{~cm}$ width, hollows, striae, separated by low lists from crystallic rocks and mounds. Linear relief of this ruggedness, often complicated with lateral footboards, can serve for determination of relative shift along the surface of fissure. The slickenlines are often seen on the grounded and finished by the friction discontinuous surface called tectonic polished surface".

And here is the description of the "glacial" striae in Geological Glossary at the same page: "Glacial grooves are formed at moving the glacier on the smoothed and polished surface of the hard rocks. They are of several meters in length, $2-5 \mathrm{~cm}$ width, and several millimeters in depth".

The parameters of the grooves are described correctly, but genesis, supposedly glacial is simply primitive. For 200 years of the glacial study one could not say a fact of the glacial scratches of the seat rocks, and the evidences of tectonic striae with crystal rocks are given by geologists, geomorphologists, tectonics researchers - in different by the age structures, but frequently in Neotectonic, including the Holocenic ones.

\section{Theory of Mountain-sheet Glaciation by Academician N. M. Strakhov}

N. M. Strakhov made his contribution to Permian-Carboniferous super glaciation [19]. He profoundly started to interpret flat- sheet glacia- tions of India and Australia into the mountainsheet ones. What was the reason? Having analyzed geographical position of the glacial sheets of Gondwana, he suddenly found that in Permoconiferous period thick sheet drifts of India and Australia were in equatorial-tropical zone of that time. In the monograph of L. B. Rukhin [30] equator is also run via India and Australia, and here on the equator massive glaciation is shown by geological triangles. L. B. Rukhin gives no comments to these diagrams. Once there are tillites and striae, so you can safely draw glaciation in equatorial zone (!) and in medium zone, and even in taiga. If near the equator thickness of the glacier was up to 5-6 $\mathrm{km}$, then in our, rather suitable for life, medium belts the ice thickness should be beyond all reason!

However, the Academician seems to find the way: he proposed to the scientific society that massive sheet glaciations appeared in equatorialtropical belts considered as mountain-sheet ones: glaciers emerged high in the mountains, expanded their thickness, produced strata of tillites, making "glacier beds", finishing their feet and producing striae and groves. Here the analytical ideas of the Academician: "When it has been clear, N. M. Strakhov writes, that the glaciers of Hindustan and Australia belong to tropical zone of the upper Carbonic and low Perm periods, their interpretation as a flat land glaciation became impossible. The only possible interpretation is the theory of HindustanAustralian glaciers as glaciations of the mountain type, appeared due to the formation of rather high raises in vernecarbonic equatorial zone".

The Academician is true in the issue that tectorial glaciers (and more precise just tillites) turned out to lie in tropical and equatorial zones of that period. His second statement causes issues:

1. What was the height and the area of mountain systems emerged on the platforms?

Let us see current largest mountain HimalayaTibet system. In this system only mountain-valley glaciation, by the way, very weak in the Tibet- the highest plateau on the Earth- is developed. And it should be noted that these mountain systems lie not in tropical and equatorial zone, but in the middle latitudes. Hence, the higher mountain systems then Himalayas-Tibet are required, and their area should be larger. Of course, for triumph of the Glacier Theory it is possible to make such assumptions, but we should also consider the data of geotectonics. They clearly specify that in Paleozoic time (including Permian-Carboniferous period) Hindustan and Australia developed in the platform mode that makes the problem of appearance of high mountain structure unreal. Even the Academician failed to advance an argument for the benefit of his mountain systems. 
2. Are there residues of the mountain structures on the platforms said or evidences of their denudation as massive accumulations of terrigenous material? We have not found.

In any case hypothetic high mountain structures are considered to be washed away by denudation next periods. But such hypothesis does not explain how, on the place of the washed mountain structures, on the denuded Pre-Cambrian base appeared the traces of exaration activity of the glacier - striae and finishing of the rock materials, as well as tillites. You know at destruction and denudation of the mountains geomorphological and geological surface traces of the glaciations should be eliminated. This is the most enigmatic point in conception said by the Academician. Can it be true that glacial synergetics is programmed in such a way that it is possible to trace its exaration activity and under the base of mountain systems - on the surface of granitic rocks and gneisses, laying Archaean - Proterozoic basement? Perhaps it is time to introduce subsurface-minery glacial exaration by analogy with heavy-dozer-glacier effect?

The Glacier Theory is so unbreakable that N. M. Strakhov does not need any evidences to place mythic surface glaciers on illusive mountain structures. But still the Book of Academician has interesting data. It concerns glaciation in Australia which the researcher focuses: "In low Carboniferous period of Australia according to the data of F. Lotze were found gypsiferous deposits (the marker of warm climate) and that means that in Low Carbonic period the North part of Australia covered by the glacier was in low latitudes that is close to the equator. Red gypsiferous beds were also found in Permian system of the West Australia. Hence, this part of Australia was also near the equator".

"Therefore, N. M. Strakhov writes, following the theory of A. Wegener on migration of continents, it should be admitted that after low Carbonic period Australia has temporarily travelled into high latitudes (close to the pole) and in the middle and Late Carboniferous period and at the beginning of the Permian system it was covered with ice, and to the upper Permian system it returned, so to say, to the primary position-low-latitude."

Further we have a remarkable conclusion of the Academician: "Deliberateness and inconsistency of this interpretation is visible by itself and it is unnecessary to treat them. The evidences showed by F. Lotze on availability of gypsiferous deposits in the Low Carboniferous and the Permian system of Australia deny the concept

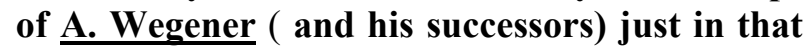
field for interpretation of which it has been so widely and with such effect used."
In its present form, as it is known, the Theory of tectonics of lithospheric platforms has went forward, but it, as it may seem strange, did not liquidate from glacial bonds and it cannot get rid of great Late Paleozoic glaciation which restrain the Theory of continents' drift movement, generally lightened by immeasurable talent and persistence of Alfred Wegener. He could not have to disprove the Glacial Theory!

Thus, to explain the glaciation of Australia and India a theory on appearance of the highest mountain systems, exceeded by all the criteria the Himalayas and Tibet, has been advanced. And what was the matter with the glaciation in Africa? When the tillites were found there in the basin of equatorial river Congo and together with striaed and polished rocks the question arose concerning the development of powerful glaciation in the tropical belt of this continent (N. A. Butakov, G. P. Leonov, P. Fourmarier). The leading Soviet geologist G. P. Leonov has analyzed geographical expansion of tillites and striation of the bed rocks in the basin of the river Congo (in the valleys of the rivers Lova, Lualaba, Lukuga, Oku) and came to radical conclusion: "The development of vast glacial sheets at the end of Carbonic period in so low latitudes of Africa and India has been possible only at significant general elevation of the continent of Gondwana and at high and vast mountains available." "Such low latitudes" are tropical and equatorial part of Africa, long basin of the river Congo (Zair). It is certainly possible to raise the highest mountains there - to place powerful glaciation on them, but it is desirable to have minor indirect evidences. But the Glacial Theory earns the title of "inviolability" - one can suggest and propose anything- no evidences are required.

One way or another, the ideas on strong mountain glaciations in Permian-Carboniferous period on the platforms of Hindustan, Africa, and Australia fell on fertile ground, the scientific society was satisfied. The researchers have forgotten very quickly that almost planetary plain glaciation was explained by them by sharp, worldwide, cosmic supercooling of climate deepened by bad cold-ice effect of albedo.

But time passed, the data on rich, gross vegetation and diverse animal world in Permian and Carboniferous period grown and lived just on the areas covered with glacial sheets multiplied (see Section "Vegetation and climate in Permo-carboniferous period").

\section{Paul Fourmarier's Paleogeographic summary}

Paul Fourmarier, the Academician of the Belgian Royal Academy of Sciences, paid a great at- 
tention to the Late Paleozoic glacial period. In his book "Problems of continents' drift" [14] he marked a number of contradictions and weaknesses in History and Geology of that epoch. He writes:

1. A great spatial extension of Permocarboniferous glaciation passing via the Equator to the North half of Africa enables us to consider that this was a unique phenomenon in evolution of the Globe.

2. It should not be leave out of account possible existence of ancient high mountain relief in Africa and, consequently, mountain-tectorial glaciation in the Equator, in the basin of the river Congo with the center of glaciation in the mountains Hakanson.

3. Gondwana glaciation was due to some geological factor just another then the drift of the continent.

4. Gondwana glaciation, obviously, invaded progressively from the South to the North, reaching the equatorial zone. It should be however marked that the relief played an important role in India, South America and Africa, Gondwana Glacier descended from the mountains, leaving after glacial grooved and polished beds and sheepback rocks.

5. Apparently neither total shift of the Earth Crust on its substrate, nor the drift of the continents can give satisfactory explanation of Permiancarboniferous glaciation.

6. We have no evidences for the existence of mountain systems in Gondwana relative to the Andes, the Ruvenzori and the Himalayas we have to suppose the higher mountain systems, only then we can state vast glaciations.

Here are the main 6 issues of P. Fourmarier determining the existence of Gondwana glacial covers, Late Paleozoic glacial period.

P. Fourmarier in his foreword to the book points that in compilation of the book and consultations a great number of the members of the Belgian Royal Academy, totally 12 scientists, has taken part. It seems that every Academician wanted to make a contribution to this fundamental work here from we have repeats in statements. The researchers erect unanimously the highest mountain structures on the platforms which do not match by geotectonic conditions to the mountain formation, but even the Academician P. Fourmarier warns: "we have no evidences on existence of mountain systems in Gondwana", but they are necessary to develop vast glaciation.
But the researchers seemed not to notice contradictions, and more over, and do not care of nobody knows how and when missed mountain structures, not thinking on inevitable in such case missing of traces of glacial exaration - groves, striae, polished glacial beds, sheepback rocks. But they, these traces, are available. They are not of glacial, but of tectonic origin.

\section{Favour from reading the Proceedings written by the Russian geologist D. V. Nalivkin}

Let us remember to the foreign and Russian scientists about the work of the Academician D. V. Nalivkin [17] - his monograph "Theory on fascias" (V2. 1956), where was spoken with authority on geological quick denudation of mountain systems of the Earth. Here are the conclusions of D. V. Nalivkin: "Nothing has been kept from Paleozoic and Mesozoic mountain ranges. Not much was kept from Paleogenic (tertiary) uplifts, but Neogenic ones survived in great extent. Valley glacial clays of Palozoic and Mezozoic age were completely destroyed along with those ranges where the valleys were, but Pliocene and Quaternary formations are of no rarity, they are common".

It is quite clear that mountain and rocks of Palezoi on which the traces and forms of relief of Permo-Carboniferous glaciation were supposedly formed have long turned into sand and clay (and then metamorphism processes turned them into sandstones and shale rocks). The same relates even to Mesozoic rocks which build the mountain uplifts up. Along with this the glacial traces attributed to the glaciers, striae, grooves, polished glacial beds, sheepback rocks, trough valleys and firths, disappeared completely.

An on the Baltic shelf where all types of "glacial-exaration" relief are represented it is clearly proved their fault-Neotectonic genesis and Quaternary, including Holocenic age. A key to a puzzle of all these glaciations- Quaternary and Paleozoic is in stacks and sheepback rocks on the Baltic and Canadian crystallic shield blocks, in the areas, in their Neotectonic fault zones (Fig. 15). The work of D. V. Nalivkin clearly shows to the activists of Glacial Theory that making the highest Paleozoic mountain structures (to create good conditions to the Glacier) they finally get denudation flat lands and the so-called "traces of the Glacier" completely disappeared. Meanwhile, the Quaternary period explained everything - "traces of the Glacier" - it is a consequence of Tectonics. 


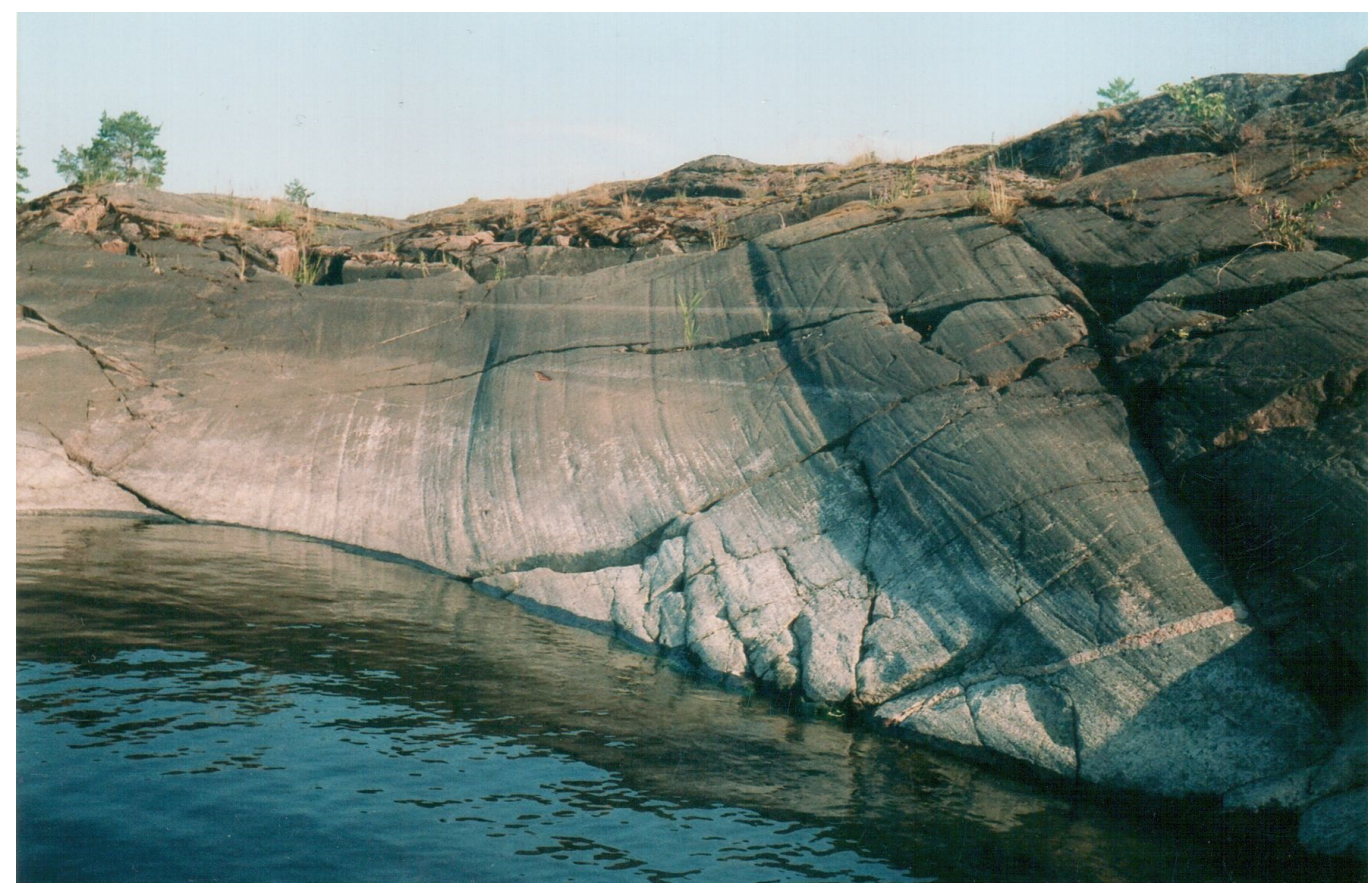

Fig. 15. Tectonic furrows and flat-lying sheepback on gabbro-norites. They were created in Golozene (post glacial) period of tectonic activation in the crest of Lake Ladoga, island Palosaary (photo by V. Chuvardinsky)

\section{Glacial wheel of the Tarlings}

In the Book of British scientists D. H. Tarling and M. P. Tarling "Moving continents" [20] a great attention was paid to Permo-carboniferous period, since it plays an important role in determining geographical position of the continents in Paleozoic period, especially in the South Hemisphere.

The researchers cover the problems as follows: "Based on current distribution of the continents, where we have the evidences of PermianCarboniferous glaciation (tillites, scratches of the rocks) it seems that it was almost complete glaciation covered in fact simultaneously the area of modern South Pole up to the Equator. Formulated differently it turns that the Earth should be covered with ice at that time" [20].

Further D. Tarling and M. Tarling suggested a new idea: "If we recombine south continents into Gondwana and let this supercontinent to cross the South polar area of the Earth slowly, then the South ice cap should "consequently migrate along the continent" (entered into circumpolar space). Such interpretation, as the researchers write further, not only explains different age of the glaciation, but results in matching climatic conditions with the position of ice cap at different periods of that epoch".

The mechanism is surely interesting and quite applicable to the glacial philosophy. An idea to pass the continents successively via the South Pole in order of their complete glaciation - while they are migrating along circumpolar space - as it turned out with an Antarctic continent is quite admissible for next hypothesis. It is important in this wheel mechanism that the continents (and subcontinents like Hindustan) should pass as quickly as possible and strictly the South Pole according to the schedule; otherwise we shall have disorder of the continents. Even the time of glacial period is geologically limited - Permo-Carboniferous glaciation according to the popular opinion was within the range between 340-240 Ma, almost all the time the Earth was under the Glacier. It is possible to add for assurance tens of millions years, but nobody decide to prolog this period, yet the authors of the Book "Winters in our Planet". Besides the desires of rapid drifts of the continents - both via the South and the North Pole, it is necessary to keep two factors:

1. Passed glacial-pole purgatory, the continents also have to enter first the medium climatic zone lost the glacial cap and then come closer to the Equator for mass carbon formation.

2. It is necessary to follow that the continents do not disturb the wheel system, do not return to the ice circumpolar space without its turn (it is necessary to prove the availability of several horizons of tillites)!

Surprisingly we have evidences for nonauthorized secondary, and even multiple returns of the continents both to the ice latitudes and multiple returns of them to the Tropics- for formation of new coal beds- an example is South America (glacial strata in Itarar, Brazil) (Fig. 16). It is interesting to know what continent repeatedly got into the pole zone from warm tropical zone like it was drawn by the South magnetic Pole. And this continent is the Antarctic. Here are the evidences: up to the present several large coal deposits were found in Antarctica (Fig. 17). 


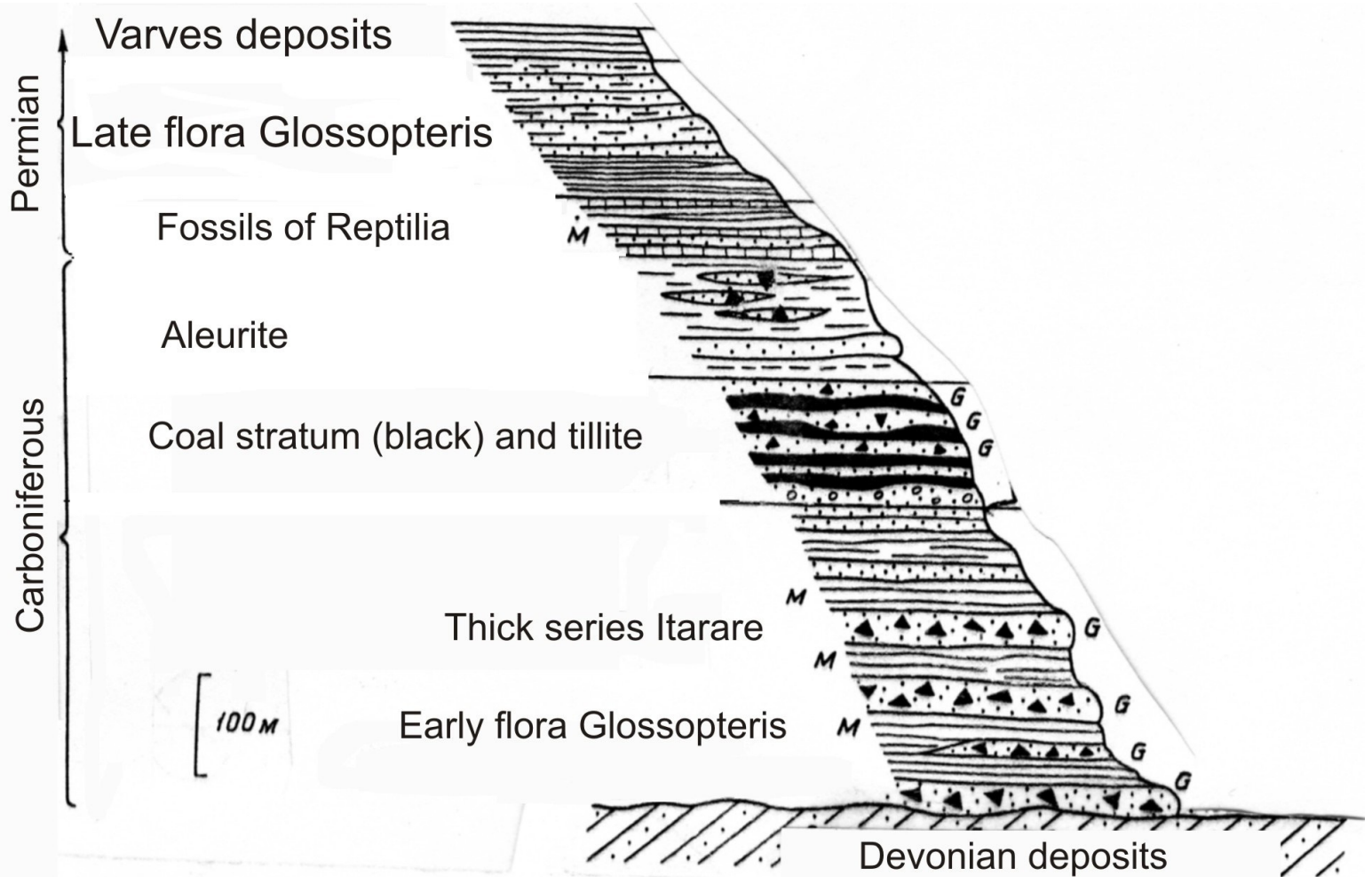

Fig. 16. A generalized stratigraphic scheme of Carboniferous and Lower Permian formations in the Southern Brazil [2]. A majority of glacial traces is attributed to rocks of the Itarare group. $M$ - marine layers; $G$ - glacial layers

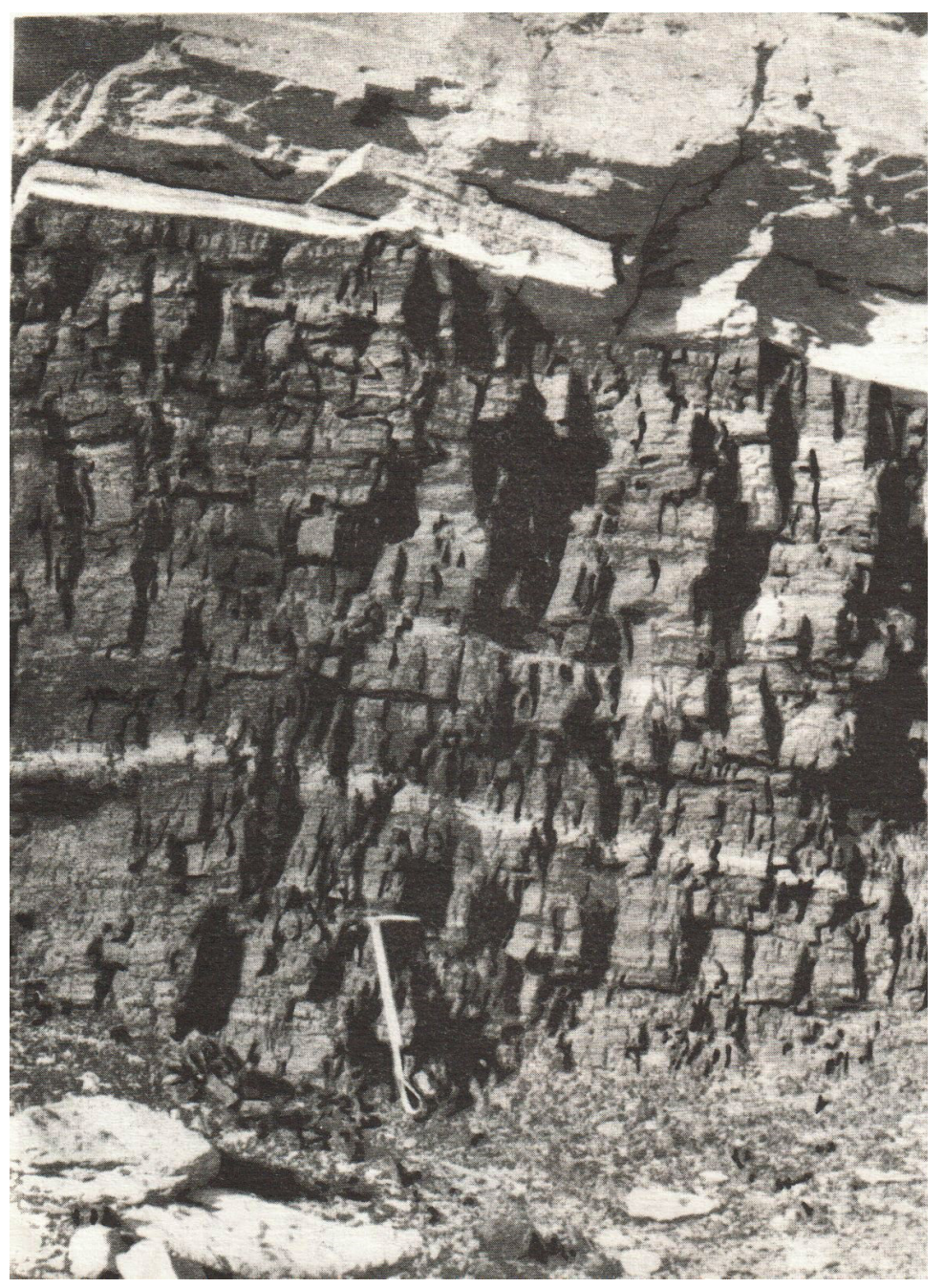

Fig. 17. A wide coal-bed, in Antarctica, the Land of the Queen of Fashion (according to V. I. Bardin [21]) 
Coal formation in Antarctica occurred in PermoCarboniferous "glacial" period. Moreover, and it is important, in several coal deposits one can observe several strata divided by the layers of "tillites and lake-glacial" metamorphose sandstones and shales. Thus, in large exposures of Late Paleozoic rocks of Bukei formations in $100^{\circ}$ of west longitude it was found 5 independent large coal strata divided by "tillites" and metamorphose "lake-glacial" shales and sandstones (P. Fourmarier [14]).

What does it mean? Did the continent Antarctica really return to the Tropics 5 times to form coal deposits and 5 times return successively into the circumpolar space to be overlaid by the tillites? It is difficult to form the layers of tillites consistently in the Tropics.

And, in fact, the whole process of coal formation occurred when the Antarctica was in subtropical climate, in its swamped deep forests. And it happened once in Permian-carboniferous "glacial" period, when Antarctica, as A. du Toit and P. Fourmarier supposed, was in the middle latitudes in the Indian Ocean (see Fig. 20). Why we have 5 coal strata? These are general cycles of coal accumulation: at different geotectonic blocks during fault-tectonic processes a part of coal strata were overlaid with the layers of tectonic breccias (mélange). And in this case the rubbles are usually water worn, polished, but have no neither striae, no grooves. And what about the Glacier? The Glacier has only dust-like material, mainly volcanic ash; its function is in conservation of geological surface.

Antarctica has started to drift to the South Pole upon formation of big coal deposits - just in Mesozoic epoch and in Neozoic period it took its circumpolar place. Its glaciation is also Neozoic. It considers that $14 \mathrm{mln}$ years ago it became a glacial continent and since then it only extended the thickness of ice, keeping its general geological subglacial surface from denudation. Could other continents or their parts repeat the fate of Antarctica? They could, geological history of the Earth from the Archaen up to the present is diverse. In order to determine was glaciation developed on certain continents one need to look for and specify the intervals in deposition of the sediments, the intervals in whole geological periods and not only the sediments deposition, but of organic life. Glacial sheets provide both reliably.

\section{Vegetation and climate in the Permian-Carboniferous period}

The most famous Soviet-post-Soviet theorist of the global glaciation of the Earth N. M. Chumakov in his book "Glaciations of the Earth" (2015) marks sections "Biospheric events and glaciation" and "Biotic events". In a rather thick book, these two sections together occupy only 2 pages and they are dedicated to the "mighty Permo-Carboniferous glaciation", during which huge coal reserves were forming, these reserves constituted half of the coal reserves of all other geological periods (excluding brown coals). N. M. Chumakov did not say a word about the occurrence of coal that gave the name to the geological period; he habitually ignores the indisputable facts that the main reserves of coal and the thickest coal seams are located on the areas of the notorious ice sheets - in South Africa, Australia and India. The glacier remains, and the duties to form coal reserves have not been canceled!

It goes without saying that there is no mention of the dense, swampy forests of the Carboniferous period - it is necessary to protect the "great glaciation" from paleontologists "intrigues"!

The following courages verses written by a paleontologist, corresponding member of the USSR Academy of Sciences, E. A. Radchenko in his "Geopoem", in the journal "Nature", 1975, No. 6, are devoted to the Carboniferous period:

The Carbon was famous with forests,

Its present was coal in the rocks.

The trunks were drowning in the swamps

And then to coal were giving birth.

Breaking what was firmly planned,

Life is coming out on land,

But peculiar reptile feature

Of the sea creates a picture.

The proponents of planetary glaciations do not need such "paleontology" and N. M. Chumakov [1] habitually emphasizes the "terrible" widespread extinction of the biota, the death of the plant and animal life - is the global glaciation is described in vain or what? Here are the statements of N. M. Chumakov: in the Carboniferous period "a mass extinction of the marine protozoa", "extinction of the climeninds and ostracods take place, a decline in the diversity of gonnatitids is noted, the placoderms are almost completely extinct, the teleosts take their place". Like he is a pathologist, who even doesn't notice that the ice age is of no threat for "teleosts" for some reason, as well as for tree ferns, tree horsetails and strong cordaites with a thickened root system that grew up in South Africa right during the Late Paleozoic glaciation (Fig. 18, 19).

And now let's see what situation really was, let's show the actual data, which is set forth in the works of paleontologists, botanists and zoologists. Scientific literature on these issues is extremely grand and capital. The above mentioned specialists could have highlighted a question of the abolition of the Permian-Carboniferous ice age long ago, but the glacier proponents constantly point out the geo- 
logical, supposedly indisputable, glacial signs - tillites, striations and furrows on rock outcrops, on roche moutonnée And the scientists who possess unique paleontological data prefer not to take risks, but to obtain high academic degrees prospectively. Nevertheless, their factual material directly and significantly contradicts the "great glaciations". Let's briefly list these important data, placed in the following textbooks for geological universities: "Historical Geology" (1974) - authors G. I. Nemkov, M. V. Muratov, I. L. Grechishnikova [21]; "Historical geology with the basics of paleontology" (1985) - authors E. V. Vladimirova, A. H. Kagarmanov, N. J. Spassky; V. V. Drushchits, O. P. Obrucheva, "Paleontology" (1971).

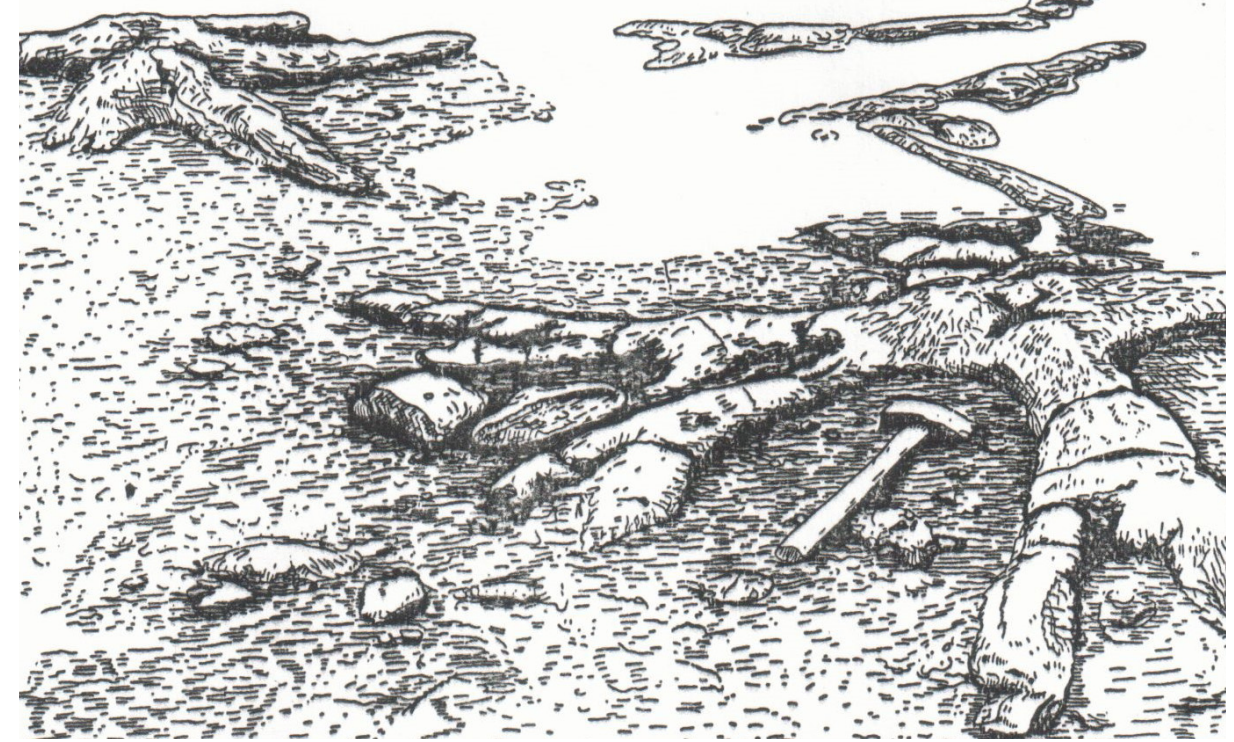

Fig. 18. Stubs of the cordaites in Permian-Carboniferous period, the valley of the river Vaal, South Africa (by A. du Toit [9])
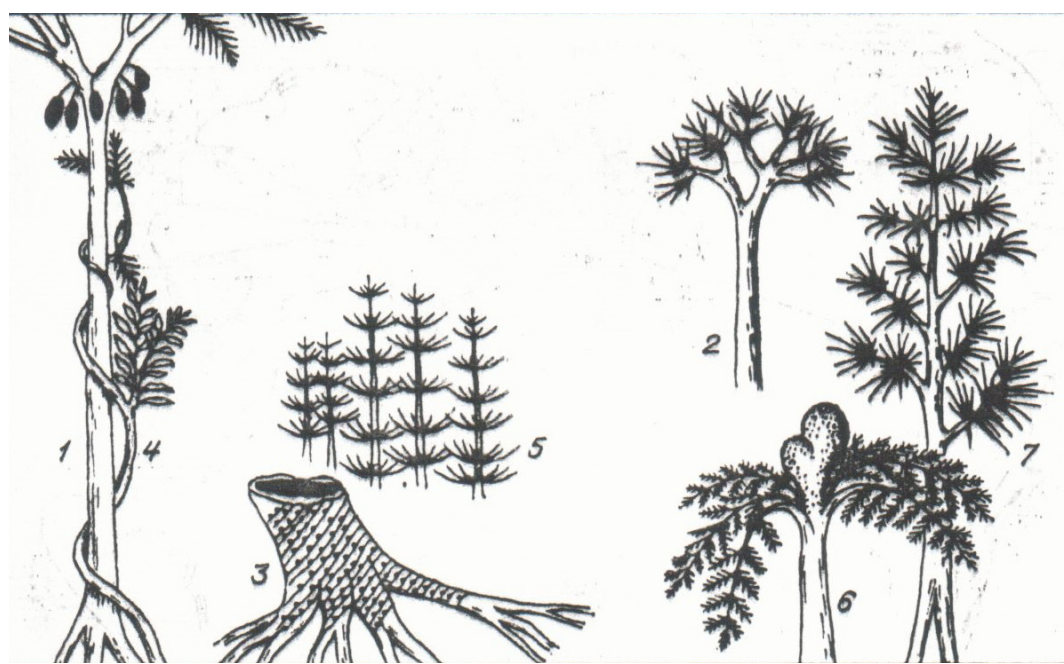

Fig. 19. Representatives of Permian-Carboniferous flora [21]: 1-3-lepidodendron (lycopsids (club mosses); 4 - liana-like seed fern; 5 - calamites (horsetails); 6 - tree fern; 7 - cordaite

\section{Carboniferous period}

In the seas of the Carboniferous period large foraminifers - fusulinidas - were widely spread; rugosa, corals, tabulate corals and bryozoans were in full swing. Sea urchins, vertebral fish, mollusks reach large sizes. Among the arthropods the armor spiders, scorpions, dragonflies with a wingspan up to $100 \mathrm{~cm}$ spread out. Stegocephalia and cotylosauria reach a great variety; the first crocodile-like creatures appear, but unlike the modern coddled crocodiles, the crocodiles of the Carboniferous and Permian glacial period were of no threat, they were much frost-resistant than our walruses! 
Carboniferous flora was formed by the evolution of the late Devonian flora, many new species appear, especially tree species - lepidodendrons, sigillaria, calamites. Gondwana (Glossopteris) flora is characterised by pteridospermatopsidas, cordaites reaching a height of $30-50 \mathrm{~m}$, with a trunk diameter of more than $0,5 \mathrm{~m}$, and herbaceous horsetail (see Fig. 19). Everything develops evolutionarily, the conclusions of glacier proponents are easily refuted.

\section{The Permian period}

Among the protozoa fusulinids, sponges are still important, the number of bivalves and gastropods enlarges, and toothy fish spread.

In the second half of Permian there was an aridification of the climate, deserts appeared, the forests were transforming into steppe. The animal life was concentrated in river valleys, in lake-marsh systems. These were the kingdoms of crocodiles, other mammal-like reptiles and amphibians. In the Gondwana region, climatic conditions remain moderately warm, carbon formation continues in Africa, India, South America, Australia. The end of the period was marked by intensive orogenic processes. Such is the development of the organic world in the "glacial" Permo-Carboniferous period. Remorse laments and incantations of N. M. Chumakov [1] on the "mass" extinction of biota and the terrible glaciospheric climate remain a religious-glacial aberration.

Let's recall that western scientists B. John, E. Derbyshire, G. Young, R. Fairbridge, J. Andrews [2] claim that the Permo-Carboniferous period was the most a severe and very long. Thick glaciers covered the Earth 340 million years ago and went away only 240 million years ago. The glaciation lasted 100 million years - almost the whole Carboniferous period and most part of the Permian period the Earth was under the glacier (see Fig. 1). Where and how the rank vegetation and rich animal life escaped from this glaciation the western (and our) scientists are silent about. They also conceal the widespread carbon formation in the ice age.

So, "sultry, heavy humid atmosphere" in the Carboniferous period and "hot vast deserts" in the Permian period. One period is a steam bath, the other is a dry sauna. How does it fit with the approved and exalted theory of a huge glaciation that covered almost the entire globe. It must be said that paleontological data, which clearly refutes the glacial constructions, is collected in exceptionally much amount.

If we compare the "scheme of global alternations of glacial periods" (see Fig. 1) with the "Ta- ble of organic life on the Earth in the Phanerozoic" (Fig. 21), then irreconcilable contradictions between the glacier proponents and the actual data of paleontology will be seen in all its glory. But it is profitable for glaciologists not to notice them.

\section{Conclusion}

\section{Glaciation and continental drift by Alfred Wegener}

Metastases of the glacial doctrine penetrated into all the sciences of the Earth, even into archeology. But if we look at the problem of glaciation philosophically, this teaching, after all, was a gift for a loner-researcher who was never part of tempting scientific ice schools.

The glacial theory reigns for two centuries and, although the throne was occupied by high class people of the highest academic rank, yet the ordinary workers conducted the fieldwork, performed a variety of laboratory studies. The data received was published and, thus, during many decades the huge amount of factual material has been collected. This material is real treasure for the researcher, who has long come to the conclusion that the glacial theory is erroneous. The main condition for reinterpreting the material, in order to take benefit from these data, was incessant geological and geomorphological field research in the main "glacialtheoretical" areas and, especially, in the citadel of glacialism - on the Baltic Shield. Why on the Baltic Shield? Because using the example of the Baltic Shield (and partially the Alps), all the main, wellknown geological and geomorphological, signs of ice sheet were developed. They related to the Quaternary glacial period, but after establishing their "unconditionally glacial" genesis, these signs quickly spread to the ancient glaciations, primarily on the Permian-Carboniferous ice age. What did my field research give? First of all, it was established that the brightest "glacial" signs - the types of exaltation relief - roche moutonnée (sheepbacks), fleecy rocks, striations, furrows, polishing of crystalline rocks, skerry relief, drumlins, lake basins in the bedrock, fjords - all these forms have a fault non-tectonic origin, and such forms of relief as eskers and "terminal moraines" are associated with fault-folded processes. As for the boulderblock deposits of the Baltic Shield, their main part is also connected with fault-tectonic processes, and the most typical "glacial" deposits containing striated boulders are in fact a tectonic breccia of friction and perform fault and near-fault zones of crushed and dislocated crystalline rocks. A number of forms and types of relief, as well as the stratal subsurface ice, have a permafrost and intrapermafrost genesis. Comprehensive evidence for 
this is given in the monographs of the author [3-5; $10-12 ; 23-28]$. All this created conditions for reinterpreting a huge "glacial heritage", including the genesis of the Late Paleozoic glaciation "traces". The principle of actualism was helpful for successful work on the reinterpretation of "glacial" materials.

However, it should be recognized that the treasure of the "glacial legacy" is in an extremely difficult situation. It is not as easy as $\mathrm{ABC}$, it requires a painstaking work by geological archivists during many months or even many years.

The difficulties mainly relate to geological and geomorphological data, and material of the plant and animal life of the Permian-Carboniferous period doesn't need help for revision - it fully reveals the landscape situation of that time, it is extremely numerous, one can say comprehensive, there was not even a hint of any ice sheets in this material. Only dense forests consisting of giant tree forms were mentioned - lycopodiums of horstails, ferns, cordaites $40 \mathrm{~m}$ high and the first coniferous and ginkgo trees which appeared in the end of the Carboniferous period and in the beginning of Permian period.

The lush vegetation promoted the colossal coal formation. Both the Northern and Southern Hemispheres are famous for the giant deposits of coal, while particularly large reserves of coal are discovered on the territories that are customary covered with thick continental ice.

The animal life on the territory of the "glaciations" was also exceptionally rich and varied, it was the kingdom of amphibians and the first reptiles, including crocodile-like, which evolved into freshwater and marine crocodiles that nowadays widely populated low and middle latitudes of the planet.

Due to the abundance and uniqueness of the factual material collected by paleontologists paleobotanists and paleozoologists, the PermianCarboniferous period is unparalleled and paleontologists could long ago question and even abolish the glacial period of this time. But they left the categorical conclusions to someone of the geologists to make. Scientific safety system was above all: geological and geomorphological signs of glaciations seemed for paleontologists to be firmly established, unshakable. But since I managed to prove that these signs have nothing to do with the glacier (they are mainly of fault-tectonic origin), I set myself the task to debunk the Late Paleozoic ice age.

The huge paleontological material already available in the works of many scientists is ultimate, irrefutable help for solving this problem. A new lease of life came after the results of the through drilling of the Greenland and Antarctic ice sheets, which showed the absence of any boulders throughout these glaciers. Instead in the thickness of the ice there are only rare dust-like and finegrained inclusions - mainly volcanic ash. Glaciological works also showed that the bottom parts of the ice are immobilized, their function is the conservation of the subglacial geological surface. Glacial paleogeographic schemes of the late Paleozoic are quite revealing - they constantly lead the palaeography nowhere. The authors of these schemes understand it quite well, but no one denied the glacier.

The hypothesis of tectonics of lithospheric plates also did not escape the impasse.

\section{Glaciations and drift of the continents according to Alfred Wegener}

The diagram of continents' disposition in the South Hemisphere in Gondwana glacial epoch, the period of Permian-Carboniferous glaciation (Fig. 20), is in the book of P. Fourmarier with reference to A. du Toit.

Australia, India, South and a part of Equatorial Africa, Madagaskar and Antarctica, which has been just placed in the Central part of the Indian Ocean, are covered by powerful ice sheet of up to $6 \mathrm{~km}$, the unified glacier sheet, in this diagram.

Such disposition of South continents (as one of the variants) is possible but with the condition - to refuse from "great glacier sheet", to eliminate "Great Permo-Carboniferous glaciation". Simply it is necessary to abandon from fault glacial features, to change them with general geological onesaccording to the principle of actualism, criteria, to bring into compliance with reach paleontological materials and the results of glaciological including drill works in Grenlandia and Antarctica. It is possible to agree with the suggested Mesozoic placement of the South continents, drift of Antarctica to the South Pole.

Alfred Lotar Wegener (1880-1930) in order to prove the validity of hypothesis of the continents drift and their grouping into the supercontinent Pangeya used an idea on "Great Late Paleozoic glacier sheet" widely. This cover with the thickness of up to 6 meters tightened firmly, connected discrete continents into integral whole. Further, many of the researchers and especially A. Du Toit, the diagram of which is given in Fig. 20, developed the idea of Vegener and his paleogeographic diagrams with certain participation of combining "Great glacier sheet".

And what happened? Nobody knows what to do with this "great glaciation". It leads to a deadlock not only paleogeography, but undermines severely the theory of the continents drift (current "Tectonics of lithospheric plates"). The scientists do not 
know how "to satisfy" the glaciation theory, how to place the continents in order to keep "Great glacier sheet" and at the same time to maintain or- ganic life on the Earth. One cannot even remember of planetary carbon formation in this glacial period.

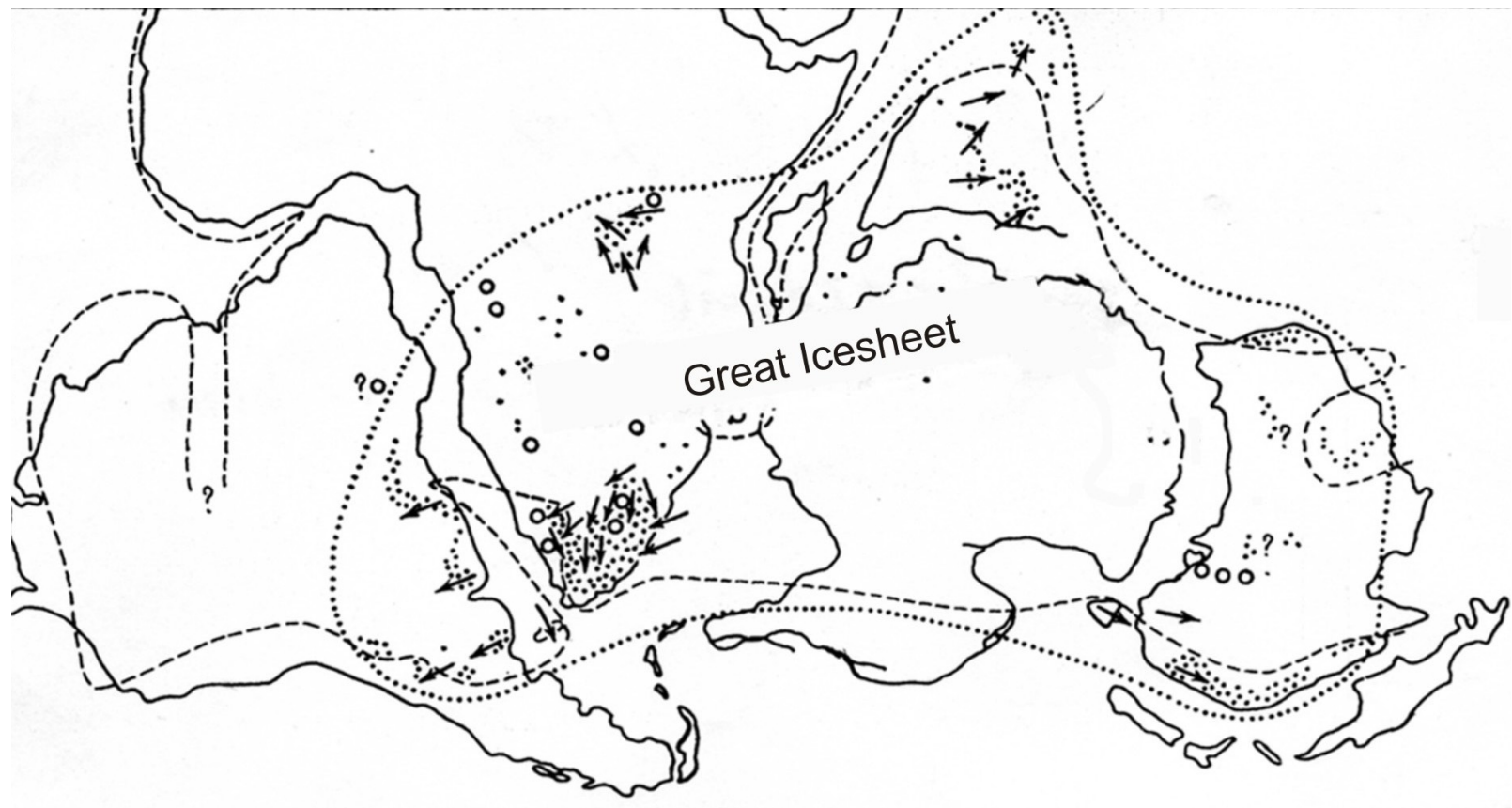

Fig. 20. Disposition of the continents in the South Semisphere in Gondwana glacial epoch (by A. du Toit [9]). Dotted lines are the areas of glacial zones at the end of the carboniferous period. Arrows show the direction of the movement of glaciers. Dash-and dash lines are the boundaries of the abundance of ice

Let's recall the findings of well-known scientists. E. S. Korotkevich [29]: "The late Carboniferous glaciation swept through so vast territory that with any continents position on the surface of the Earth ... the glaciation still covers almost the entire Earth."

P. Fourmarier [14]: "The significant territorial expansion of the glaciation passing beyond the equator to the north allows us to believe that this was an exceptional phenomenon in the geological evolution of the Earth." And further: "Apparently no satisfactory explanation of this glaciation can be given either by the general movement of the earth's crust on its substratum, nor by the continental drift."

D. Tarling, M. Tarling [20]: "It seems that it was almost a complete glaciation covering simultaneously the territory from the modern South Pole to the Equator, in other words it follows that the entire globe in the late Paleozoic must be covered with ice."

L. B. Rukhin [30]: "The Upper Paleozoic glaciation is one of the geological riddles, it appeared on the areas at a great distance from each other, so if you move one of these areas to the pole in thought, the others will be located almost at the equator." L. B. Rukhin thinks about the glaciation of Pangea skeptically as well: "If all the continents in the Upper Paleozoic were connected the same way that Wegener depicts, then the appearance of large glaciers within this vast continent would be excluded due to the dryness of the climate."
Other scientists - N. M. Strakhov, G. P. Leonov, N. A. Butakov, P. Fourmarier also believe that the plain-cover glaciation in the equatorial and tropical zones of the Late Paleozoic time should be replaced by mountain-cover glaciers. This primarily concerns Australia, India, and Central Africa.

Admitting that it really would be useful to build high mountain constructions near the equator - for the development of glaciation, they immediately write about the absence of such mountains signs. So P. Fourmarier [14] admits: "We have no evidence of the uplands existence in Gondwana time near the equatorial such as the Andes, Ruwenzori or the Himalayas!" As we see, the "great glaciation" only leads to confusion, to destruction of paleogeographical and geological constructions. Scientists are trying their best - they erect mountain structures on the equator, they begin to move the poles, but they can not cope with the ice sheets. Even arbitrary manipulation with the continental location does not help, everything is in vain.

Maybe just "go ahead and abolish" them? No, not the equators and the poles - they should remain, but the "great glacial sheets." Then the above mentioned "scheme of the Southern Hemisphere continental location" will be fully operational.

It would be very useful for the scientists to appeal to the well-known "Table of Life" on our planet in the post-Precambrian time (in the Phanerozoic) (see Fig. 21). 


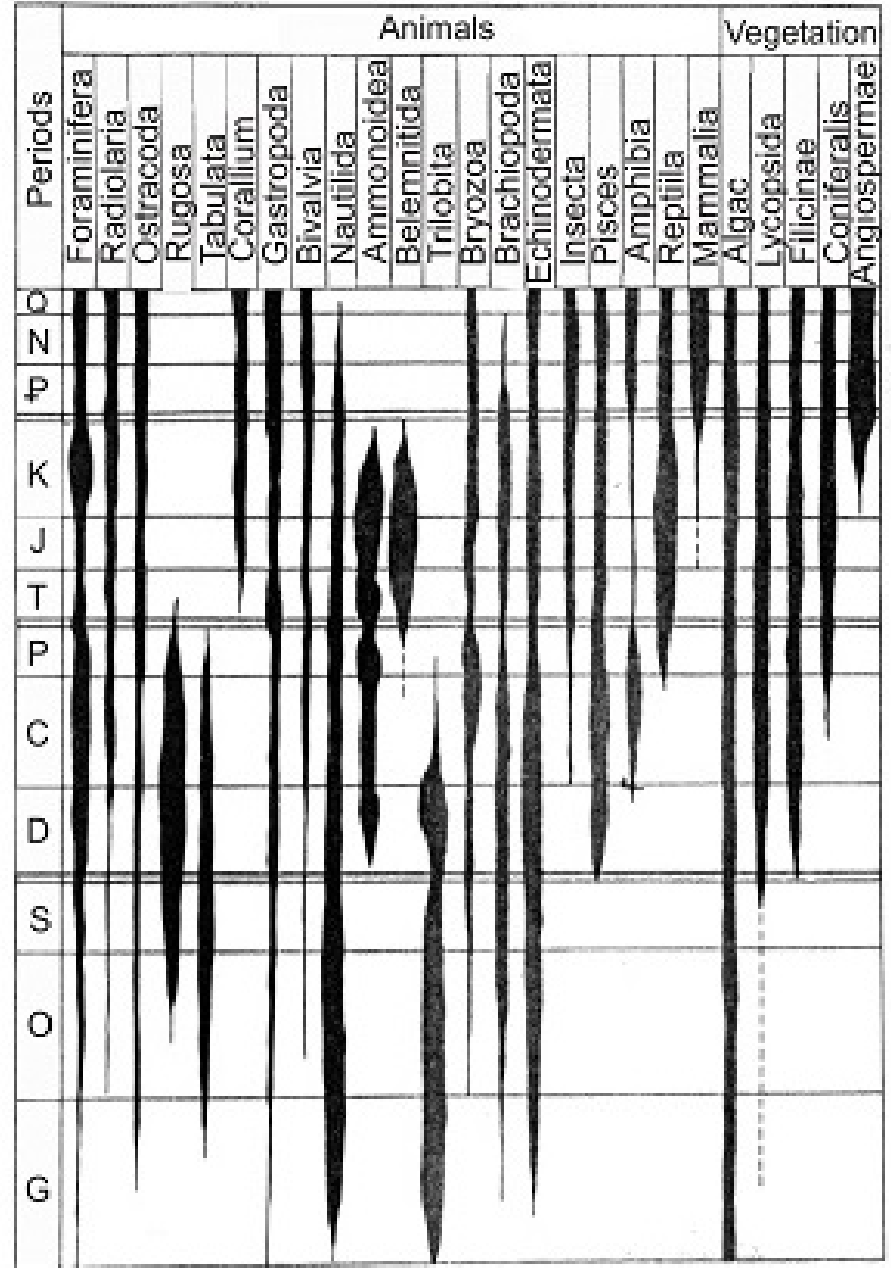

Fig. 21. Table of organic life on the Earth in Fanerozoic period (by G. I. Nemkov, M. V. Muratov, I. A. Grechishnikova etc. [22])

It clearly shows the evolutionary development of vegetation and animal life in different geological and biological periods and it is clear that organic life is not interrupted anywhere by "great glaciations". Moreover, during the most terrible PermoCarboniferous "glacial period" there is a magnificent steady peak of the organic life of the Earth.

Speaking about the issue of the continental glaciation, in different geological periods, some continents or another could be covered by glacial shields, if they found themselves in circumpolar spaces while drifting. As it happened in the Cenozoic to Antarctica and Greenland.
But how to find signs, how to detect traces of Mesozoic or Paleozoic glaciation and thereby determine the position of the poles of the Earth? Since the glaciers take on a role of conservation, preservation of the subglacial geological surface, they leave no noticeable traces of their activity and therefore one should try to find the absence of traces of organic life on certain territories. Such "dead" territories stayed under the glacier for whole geological periods and in this case, correlative deposits of the corresponding geological periods will be absent on the former ice-covered continents. Probably the unusual traces of erosion are the consequence of accumulated ice strata melting.

\section{Библиографический список}

1. Чумаков, Н. М. Оледенения Земли. История, стратиграфическое значение и роль в биосфере / Н. М. Чумаков. - М. : ГЕОС, 2015. - $151 \mathrm{c}$.

2. Джон, Б. Зимы нашей планеты. Земля подо льдом / Б. Джон, Э. Дербишер, Г. Янг, Р. Фейбридж, Дж. Эндрюс. - М. : Мир, 1982. - 336 с.

3. Чувардинский, В. Г. Неотектоника восточной части Балтийского щита / В. Г. Чувардинский. - Апатиты : КНЦ РАН, 2000. - $287 \mathrm{c.}$

4. Чувардинский, В. Г. Четвертичный период. Новая геологическая концепция / В. Г. Чувардинский. - Апатиты : КНЦ РАН, 2012. - 180 с. 
5. Chuvardinsky, Vasily. Quaternary relief on the Baltic Shield. Continental glacier or fault neotectonics? / Vasily Chuvardinsky. - Saarbrücken : Lambert Academic Publishing, 2014. - 122 p.

6. Короновский, Н. В. Общая геология / Н. В. Короновский. - М. : Изд-во КДУ, 2006. - 528 с.

7. Чувардинский, В. Г. Результаты сквозного разбуривания ледниковых покровов Арктики и Антарктиды и их значение для решения проблем четвертичного периода / В. Г. Чувардинский // Известия РГО. - 2012. Т. 144, вып. 2. - С. 28-41.

8. Evenson, E. Debris transport mechanisms at active glacier margins: Alaskan lace studies / E. Evenson. M. Clinch // Geol. Surv. of Finland, sp. pap. N 3, Espoo. - 1987. - P. 111-136.

9. Тойт, А. дю. Геология Южной Африки / А. дю Тойт. - М. : Изд-во ИЛ, 1957. - 490 с.

10. Чувардинский, В. Г. Методология валунных поисков рудных месторождений / В. Г. Чувардинский. - М. : Недра, 1992. - 140 с.

11. Чувардинский, В. Г. Разрывная неотектоника и новые поисковые методики / В. Г. Чувардинский. - Апатиты : КНЦ РАН, 2001. - 100 с.

12. Chuvardinsky, Vasily. Fault neotectonics - a metodic basis of boulder prospecting for ore deposits / Vasily Chuvardinsky. - Apatity : Print. Kola Science Center RAS, 2002. - 71 p.

13. Кришнан, М. С. Геология Индии и Бирмы / М. С. Кришнан. - М. : Изд-во ИЛ, 1954. -424 с.

14. Фурмарье, П. Проблемы дрейфа континентов / П. Фурмарье. - М. : Изд-во ИЛ, 1971. - 255 с.

15. Леонов, Г. П. Историческая геология / Г. П. Леонов. - М. : Изд-во МГУ, 1956. - 364 с.

16. Шварцбах, М. Великие памятники природы / М. Шварцбах. - М. : Мир, 1973. - 331 с.

17. Наливкин, Д. В. Учение о фациях / Д. В. Наливкин. - М. : Изд-во Академии Наук, 1956. - Т. 2. - 393 с.

18. Dunbar, C. O. Discussions. Validity of the criteria for Lower Carboniferous in Western Argentina / C. O. Dunbar. New York, 1940. - 25 p.

19. Страхов, Н. М. Основы теории литогенеза / Н. М. Страхов. - М. : Изд-во Академии Наук, 1960. - Т. 1. $212 \mathrm{c}$.

20. Тарлинг, Д. Движущиеся материки / Д. Тарлинг, М. Тарлинг. - М. : Мир, 1973. - 104 с.

21. Бардин, В. И. В горах и на ледниках Антарктиды / В. И. Бардин. - М. : Знание, 1989. - 192 с.

22. Немков, Г. И. Историческая геология с основами палеонтологии / Г. И. Немков, М. В. Муратов, И. Л. Гречишникова. - М. : Недра, 1974. - 319 с.

23. Чувардинский, Василий. Четвертичный период. Новая геологическая концепция / Василий Чувардинский. Саарбрюккен : Lambert Academic Publishing, 2013. - 302 c.

24. Чувардинский, Василий. Было ли материковое оледенение Европы? Мифы и реальность / Василий Чувардинский. - Саарбрюккен : Lambert Academic Publishing, 2014. - 275 c.

25. Чувардинский, Василий. Дискуссия с ледниковым учением. Ледниковые покровы или разломная неотектоника / Василий Чувардинский. - Саарбрюккен : Lambert Academic Publishing, 2015. - 331 c.

26. Чувардинский, В. Г. Букварь неотектоники. Новый взгляд на ледниковый период / В. Г. Чувардинский. Апатиты : КНЦ РАН, 2008. - 86 с.

27. Чувардинский, В. Г. О ледниковой теории. Происхождение образований ледниковой формации / В. Г. Чувардинский. - Апатиты : КНЦ РАН, 1998. - 302 с.

28. Чувардинский, Василий. Проблема покровных оледенений Арктики и Субарктики. Геолого-тектонические и гляциологические доказательства системной ошибочности устоев и критериев ледниковой теории / Василий Чувардинский. - Саарбрюккен : Lambert Academic Publishing, 2016. - 194 с.

29. Короткевич, Е. С. Полярные пустыни / Е. С. Короткевич. - Л. : Гидрометеоиздат, 1972. - 420 с.

30. Рухин, Л. Б. Основы общей палеогеографии / Л. Б. Рухин. - Л. : Гостоптехиздат, 1962. - 628 с.

\section{References}

1. Chumakov N. M. Oledeneniya Zemli. Istoriya, stratigraficheskoe znachenie i rol'v biosfere [Glaciations of the Earth. History, stratigraphic significance and role in the biosphere]. Moscow: GEOS, 2015, $151 \mathrm{p}$.

2. Dzhon B., Derbisher E., Yang G., Feybridzh R., Endryus Dzh. Zimy nashey planety. Zemlya podo l'dom [Winters of our planet. Earth under ice]. Moscow: Mir, 1982, 336 p.

3. Chuvardinskiy V. G. Neotektonika vostochnoy chasti Baltiyskogo shchita [Neotectonics of the eastern part of the Baltic Shield]. Apatity: KNTs RAN, 2000, 287 p.

4. Chuvardinskiy V. G. Chetvertichnyy period. Novaya geologicheskaya kontseptsiya [Quarternary period. New geological conception]. Apatity: KNTs RAN, 2012, 180 p.

5. Chuvardinsky Vasily. Quaternary relief on the Baltic Shield. Continental glacier or fault neotectonics? Saarbrücken: Lambert Academic Publishing, 2014, 122 p.

6. Koronovskiy N. V. Obshchaya geologiya [General geology]. Moscow: Izd-vo KDU, 2006, 528 p.

7. Chuvardinskiy V. G. Izvestiya RGO [Bulletin of the RGS]. 2012, vol. 144, iss. 2, pp. $28-41$.

8. Evenson E., Clinch M. Geol. Surv. of Finland, sp. pap. N 3, Espoo. 1987, pp. 111-136.

9. Toyt A. dyu. Geologiya Yuzhnoy Afriki [Geology of South Africa]. Moscow: Izd-vo IL, 1957, 490 p.

10. Chuvardinskiy V. G. Metodologiya valunnykh poiskov rudnykh mestorozhdeniy [Methods of boulder prospecting of ore deposits]. Moscow: Nedra, 1992, 140 p. 
11. Chuvardinskiy V. G. Razryvnaya neotektonika i novye poiskovye metodiki [Explosive neotectonics and new exploratory techniques]. Apatity: KNTs RAN, 2001, 100 p.

12. Chuvardinsky Vasily. Fault neotectonics - a metodic basis of boulder prospecting for ore deposits. Apatity: Print. Kola Science Center RAS, 2002, 71 p.

13. Krishnan M. S. Geologiya Indii i Birmy [Geology of India and Burma]. Moscow: Izd-vo IL, 1954, 424 p.

14. Furmar'e P. Problemy dreyfa kontinentov [Issue of continental drift]. Moscow: Izd-vo IL, 1971, 255 p.

15. Leonov G. P. Istoricheskaya geologiya [Historical geology]. Moscow: Izd-vo MGU, 1956, 364 p.

16. Shvartsbakh M. Velikie pamyatniki prirody [Great natural monuments]. Moscow: Mir, 1973, $331 \mathrm{p}$.

17. Nalivkin D. V. Uchenie o fatsiyakh [Facies studies]. Moscow: Izd-vo Akademii Nauk, 1956, vol. 2, 393 p.

18. Dunbar C. O. Discussions. Validity of the criteria for Lower Carboniferous in Western Argentina. New York, 1940, $25 \mathrm{p}$.

19. Strakhov N. M. Osnovy teorii litogeneza [Fundamentals of the lithogenesis theory]. Moscow: Izd-vo Akademii Nauk, 1960, vol. 1, 212 p.

20. Tarling D., Tarling M. Dvizhushchiesya materiki [Continental Drift]. Moscow: Mir, 1973, 104 p.

21. Bardin V. I. V gorakh i na lednikakh Antarktidy [In the mountains and on the glaciers of Antarctica]. Moscow: Znanie, 1989, 192 p.

22. Nemkov G. I., Muratov M. V., Grechishnikova I. L. Istoricheskaya geologiya s osnovami paleontologii [Historical geology with the fundamentals of paleontology]. Moscow: Nedra, 1974, 319 p.

23. Chuvardinskiy Vasiliy. Chetvertichnyy period. Novaya geologicheskaya kontseptsiya [Quarternary period. New geological conception]. Saarbryukken: Lambert Academic Publishing, 2013, 302 p.

24. Chuvardinskiy Vasiliy. Bylo li materikovoe oledenenie Evropy? Mify i real'nost' [Was there any continental glaciation of Europe? Myths and reality]. Saarbryukken: Lambert Academic Publishing, 2014, 275 p.

25. Chuvardinskiy Vasiliy. Diskussiya s lednikovym ucheniem. Lednikovye pokrovy ili razlomnaya neotektonika [Controversy about the glacial theory. Ice sheets or breach neotectonics]. Saarbryukken: Lambert Academic Publishing, 2015, $331 \mathrm{p}$.

26. Chuvardinskiy V. G. Bukvar' neotektoniki. Novyy vzglyad na lednikovyy period [ABC book of neotectonics. New look at the Ice Age]. Apatity: KNTs RAN, 2008, 86 p.

27. Chuvardinskiy V. G. O lednikovoy teorii. Proiskhozhdenie obrazovaniy lednikovoy formatsii [On the glacial theory. Origin of buildups of glacial formation]. Apatity: KNTs RAN, 1998, 302 p.

28. Chuvardinskiy Vasiliy. Problema pokrovnykh oledeneniy Arktiki $i$ Subarktiki. Geologo-tektonicheskie $i$ glyatsiologicheskie dokazatel'stva sistemnoy oshibochnosti ustoev i kriteriev lednikovoy teorii [Issue of glaciations in the Arctic and Subarctic. Geological, tectonic and glaciological evidence of systemic error in the foundations and criteria of the glacial theory]. Saarbryukken: Lambert Academic Publishing, 2016, 194 p.

29. Korotkevich E. S. Polyarnye pustyni [Arctic deserts]. Leningrad: Gidrometeoizdat, 1972, 420 p.

30. Rukhin L. B. Osnovy obshchey paleogeografii [Fundamentals of general paleogeography]. Leningrad: Gostoptekhizdat, 1962, 628 p. 